\title{
A individualização da pena no Direito Penal Comparado latino-americano*.
}

\author{
Moacyr Benedicto de Souza
}

I.

\section{O Direito Penal Comparado latino-americano.}

1. Comparar é cotejar, confrontar, examinar, ao mesmo tempo, as semelhanças e diferenças. LITTRÉ dizia mesmo que a comparação é o processo lógico a que o espírito humano mais freqüentemente recorre.

Depois do papel saliente desempenhado pela comparação no estudo e desenvolvimento das ciências físicas e naturais, línguas, psicologia experimental e outros campos das indagações humanas, seria estranho que ela não penetrasse também os domínios das ciências jurídicas.

Surge, então, como poderoso instrumento de trabalho, como elemento valioso no processo de aperfeiçoamento da tarefa legislativa de todos os povos cultos, o Direito Comparado, cuja missão se traduz em indagar do conteúdo e do alcance dos diversos institutos jurídicos, principalmente das nações com afinidade cultural, não através de simples exame superficial de normas, mas perquirindo com profundidade as razões de cada diferença ou semelhança. Velho em suas origens, pois deita raízes na Politica de

* Trabalho apresentado à Cadeira de Direito Penal Comparado, do 2.0 ano do Curso de Especialização da Faculdade de Direito da Universidade de São Paulo. Prêmio "Alcântara Machado" de Direito Penal de 1963, conferido pela Sociedade de Medicina Legal e Criminologia de São Paulo. 
Aristóteles e na obra dos doutrinadores e legisladores romanos, sem passar despercebido ao Direito medieval, adquire, entretanto, grande significado, no século passado, com Henry Meine, Albert Herman Post e, notadamente, Montesquieu, em seu Espírito das Leis.

Foi, todavia, em 1900, com o $1 .^{\circ}$ Congresso de Direito Comparado, reunido em Paris, que se iniciou a fase decisiva dêsses estudos, com a sistematização de seus propósitos, através dos trabalhos de grandes comparatistas, como Lambert, Saleilles e Levy-Ullmann. Fixados seus rumos, criaram-se, em seguida, diversos institutos anexos às cátedras universitárias, com a finalidade de melhor coordenar seus estudos e alargar a pesquisa comparatista.

Embora ainda reine acentuada divergência no que diz respeito à natureza do Direito Comparado, pois para alguns juristas, entre os quais Saleilles, Gutteridge e RenÉ David, não passa de simples método auxiliar da crítica legislativa, enquanto que para outros, com mais razão, entre êles incluindo-se a maioria dos modernos comparatistas, como MARc Ancel, é uma nova ciência jurídica autônoma, o certo é que êsse fecundo campo do Direito "representa notável meio de alargar nossa experiência jurídica no espaço, paralelamente ao que a História do Direito representa na órbita do tempo", segundo o entender de Ascarelli ${ }^{1}$.

2. Dentre as tarefas atribuídas ao Direito Comparado, LAMBERT coloca em plano destacado a da obtenção de um Direito comum legislado. No citado Congresso de 1900, encarregado que foi de sintetizar o pensamento das diferentes correntes que debatiam as finalidades da comparação no campo jurídico, LAMbert concluia que, com pequenas discrepâncias, uma das tarefas primordiais era a da unificação dos Direitos dos povos de culturas afins, quer pela criação de princípios comuns, quer pela formação de

1. Tuluto Ascarelli, Premissas ao Estudo do Direito Comparado, na "Revista Forense", Vol. 90, 1942, p. 295. 
"arquétipos ideais", como preferia Saleilles, que serviriam de base para a elaboração das diferentes legislações.

Na verdade, o problema da unificação dos Direitos dos povos de culturas mais ou menos afins vem de longa data. Um Direito unificado - nos dá conta a História - não é de todo utópico, pois um Direito comum já existiu, vigorando em todos os territórios conquistados pelos romanos, tanto na Itália como no Oriente.

Todavia, a partir do século passado, se vêm intensificando as tentativas para a unificação de certos institutos jurídicos. Na América, a questão tem sido objeto de estudos em diversos congressos e, especialmente, nas conferências pan-americanas, como a de Montevidéu de 1933, e a de Lima, em 1938. Nesta última, foi mesmo proposta a unificação de todos os Direitos da América Latina em códigos comuns, enquanto que, na Conferência Internacional de Advogados, realizada no Rio de Janeiro, Ernesto Cordeiro Alvarez sustentava a possibilidade da elaboração de um Direito latino-americano, afirmando que "los códigos latinoamericanos tienen una tradición común y si los comparamos, si bien sus principios no son, diriamos, exatamente iguales, são fundamentalmente semejantes"2.

O Código Bustamante, votado em 1928, em Havana, e vigorando em quinze países americanos, constitui notável exemplo das possibilidades de unificação no campo do Direito privado.

No que respeita ao Direito Penal, já em 1902, as Repúblìcas centro-americanas firmavam uma convenção visando unificar sua legislação repressiva, especialmente no setor da aplicação das penas. Entre nós, em 1939, quando se elaboravam os projetos de reforma das leis penais do Brasil, Argentina e Chile, HaEcKel de Lemos propugnava pela aceitação de um mesmo código para os três países, como passo inicial para a total codificação penal sul-americana. E afirmava: "Não se pode fazer obra de codificação entre

2. MARC ANCEL e outros, Jornadas Franco-Latino-Americanas de Derecho Comparado, Uruguai, 1951, p. 88. 
países soberanos, se não se inicia a tarefa por suas leis penais, por suas leis de repressão, por suas leis de segurança. Feitas essas, há entre êles um trato, uma aliança, a maior aliança possível - a defesa por igual de suas soberanias, de suas instituições e da própria sociedade. Amparados todos os países por códigos penais iguais, tanto quanto possível unidos pelos laços da defesa jurídica, tudo o mais será relativamente fácil para que tenham tôdas as nações a mesma vista no campo do cenário internacional"3.

Recentemente, noticiou-se que, por iniciativa do Instituto de Ciências Penais do Chile, está sendo elaborado um projeto de Código Penal latino-americano, para o qual foi solicitada a colaboração do Prof. Roberto Lyra. Nesse estatuto, segundo ainda as mesmas fontes, mereceriam especial destaque para um disciplinamento unitário, entre outros, dispositivos tendentes a coibir a propaganda de guerra, os preconceitos raciais e religiosos, o abuso do poder econômico, o enriquecimento ilícito, bem como a violação de tratados e imunidades diplomáticas.

Num plano mais amplo, e envolvendo as codifiçações penais de todos os povos cultos, a unificação de muitos dos institutos penais vem sendo preconizada e recomendada pelas conferências internacionais para a unificação do Direito Penal, não faltando também, nesta ordem de considerações, os esforços isolados de alguns penalistas ilustres, entre os quais o Prof. Francesco Consentrini, que, em 1938, elaborou um "Projeto de Código Penal Internacional", com 1.314 artigos.

3. Julgamos ser perfeitamente correto falar-se em um Direito Penal latino-americano. Efetivamente, não só pelas suas origens como também pela semelhança inequívoca que se observa na maioria de seus princípios e institutos, os códigos penais da região centro-sul das Américas nos

3. Haeckel De Lemos, Um Código Penal para a América do Sul, na "Revista de Direito Penal", Vol. XxIv, Fasc. I, 1939, p. 103 a 104. 
mostram apreciável unidade, difìcilmente observada em outras regiões do globo.

A maioria dêsses códigos tomou por base o modêlo espanhol da época de sua elaboração, sendo que alguns transcreveram quase que literalmente a lei em que se fundamentaram. O da Bolívia (1834), o mais antigo do continente, é cópia fiel do Código espanhol de 1822; o do Chile (1874) segue o espanhol de 1850 , embora de início o projeto tomasse por modêlo o Código belga de 1867; os da Nicarágua (1891), El Salvador (1904) e Honduras (1906) acompanham o espanhol de 1870; o de Pôrto Rico (1902) é calcado no estatuto penal da Califórnia, que, como se sabe, é de inspiração espanhola; o do Paraguai (1910), embora com raízes no Projeto Tejedor da Argentina, que se fundamentou no Código bávaro, revela também forte influência das leis repressivas espanholas; o da Argentina (1922), tècnicamente ligado ao Direito italiano, não se afastou de todo do espanhol, pôsto que alguns de seus preceitos, como os relativos à legítima defesa, aos crimes contra a honra e aos delitos patrimoniais, entre outros, são meras cópias dos dispositivos correspondentes na lei penal da Espanha; o do Peru (1924), que tomara por guia o Projeto suíço de Stooss, acabou por seguir o argentino de 1922; o do México (1931) é eclético e não se fixou em nenhum modêlo, inspirando-se, todavia, na doutrina dos penalistas espanhóis Luis Jiménez de Asúa, Quintiliano Saldaña e EugÊnio Cuello Calón, segundo revelam seus comentadores; o de Cuba (1936) fundamentou-se no espanhol de 1928; o da Guatemala (1936) guiou-se pelo espanhol de 1870, embora com preceitos inspirados na reforma espanhola de 1932; e o do Equador (1938), com filiação ao estatuto belga, mantém, entretanto, preceitos inspirados nas leis penais da Espanha.

São de origem francesa os códigos da República Dominicana (1884) e do Haiti (1835), meras traduções do Código de Napoleão de 1810, enquanto que a influência do Direito italiano se fêz sentir nos atuais códigos do Panamá (1922) e da Venezuela (1926), através do Código Zanardelli, e no 
do Uruguai (1933), que se alicerçou no Código Rocco, embora atenuado pela orientação liberal de Iruneta Goyena.

O Código do Brasil, por seu turno, ligou-se aos modelos italiano e suíço, embora Nélson Hungria, um dos membros. da comissão revisora do primitivo projeto, tenha dito "que respigamos para o efeito de algumas retificações nos Códigos Penais suiço, dinamarquês e polonês"4.

Ern 1830, a América Latina produziu um grande monumento legislativo, o Código Criminal do Império do Brasil. Louvado em tôda parte como um dos mais perfeitos do mundo, foi analisado e comentado nas cátedras dos institutos universitários das nações mais adiantadas, inclusive' por Mittermeyer, em Heidelberg.

Contendo sábias inovações e avançada política criminal, como a adoção do sistema de circunstâncias agravantes. e atenuantes para a dosagem da pena, a instituição do diamulta e do dolo eventual, o Código de 1830 influenciou decisivamente o Código espanhol de 1848, e, através dêste, os de 1850 e 1870 . Tendo em conta que êstes últimos estatutos penais serviram de base para a elaboração da maioria: dos códigos hispano-americanos, temos que concluir, para glória nossa, que na raiz do Direito Penal da América Latina encontra-se o Direito Penal brasileiro, através da notável obra de Bernardo Pereira de Vascondelos.

4. Se é notória a instabilidade do Direito Penal no: seu confronto, principalmente, com as normas do Direito Civil, conforme amplamente demonstrara o Prof. NoÉ Azevedo, em tese apresentada ao Congresso Jurídico Nacional de $1943^{5}$, na América Latina, com exceção do que ocorre na Bolívia, Chile e República Dominicana, que mantêm ainda suas leis repressivas promulgadas no século passado, tal fenômeno assume contornos dos mais expressivos.

4. NÉLSON HUNGRIA, Novas Questões Jurídico-Penais, Rio, 1944, p. 30 .

5. NoÉ AZEvedo, Notas Jurídicas, S. Paulo, 1941, p. 106. a. 107. 
Mal é pôsto em vigor um código e já se iniciam os movimentos objetivando sua substituição ou reforma. E o que é pior: no mais das vêzes, as mudanças são feitas com total subversão em sua orientação filosófica e em sua filiação doutrinária. Com isso, as leis penais não podem cumprir sua tarefa, sendo levadas, desde logo, ao malôgro e ao descrédito, esquecendo-se, como assinala Asúa, de "que un Código precisa, como los seres humanos y irracionales, una larga etapa de existencia para no frustrar su destino", pois é fato sabido que uma lei só vive se se aplica.

Pois bem. Na Argentina, onde a falta de estabilidade no campo do Direito Penal é a mais acentuada, desde 1867, quando apareceu o Projeto Tejedor, até os nossos dias, entre lentativas de reforma e códigos promulgados, contam-se nada menos que dezesseis, inclusive o excelente Projeto Soler de 1960. A Venezuela, por sua vez, a partir de 1863, sem contar os projetos rejeitados ou ignorados, pôs em vigor nada menos do que sete códigos. O mesmo se diga do. Panamá, Colômbia, Costa Rica, Uruguai, Peru e Brasil, enquanto que nos demais paises, embora mais atenuado, tal fenômeno também se observa.

A que atribuir essa acentuada instabilidade reinante nas codificações penais da América Latina?

Asúa considera a Escola Positiva a principal responsável por êsse desassossêgo que impera, de modo geral, no Direito Penal legislado, afirmando mesmo que "cuando el positivismo deje de pugnar por la reforma legislativa, todos esos males y simulaciones cesarán"

Entendemos nós que as causas são várias e complexas. Entre elas, deixando de lado as de natureza puramente filosóficas, destacamos, desde logo, o velho costume de confiar-se a um só jurista a elaboração de um código, pois ao invés de fazer um "projeto", acaba, quase sempre, por organizar um "Tratado", no qual procura tão-sòmente

6. LuIS Jiménez de AsúA, Códigos Penales Iberoamericanos, Vol. I, Caracas, 1946, p. 183.

7. LUIS JiméNEZ DE AsÚA, ob. cit., p. 186. 
difundir suas idéias, esquecido de que um código, na sua promulgação, conforme acentua MARC $\mathrm{ANCEL}^{8}$, deve indicar o estado de uma consciência legislativa do país. Por outro lado, a falta de recursos e de estabelecimentos adequados para o cumprimento das medidas que preconizam se têm constituído em fator de descrédito dos estatutos penais, pois impossibilita sua total aplicabilidade. A tudo isso se deve acrescentar, ainda, a razão posta em destaque por Cuello Calón, em seu "Derecho Penal de las Ditaduras", ou seja, a instabilidade dos regimes políticos que, na América Latina, assume aspectos ainda bem mais graves, a ponto de JoAQUim Nabuco afirmar, já em 1895, com certa ironia, que seria de grande utilidade a criação nas Universidades americanas de cátedras de Revolução Comparada9 .

5. Acompanhando e acolhendo, dentro das condições que lhes são próprias, as conquistas do moderno Direito Penal, as codificações latino-americanas não se mostraram insensíveis às reais vantagens que pode oferecer o instituto da individualização da pena, dentro de uma sábia política criminal.

Aceito amplamente por alguns códigos e mais timidamente por outros; agitando a doutrina e a jurisprudência dos países que, neste século, ainda não alteraram suas legislações repressivas, o problema da adequação da pena à pessoa do delinqüente constitui, sem dúvida, um dos mais notáveis exemplos da vitalidade do Direito Penal Comparado latino-americano.

Realmente, é dos mais expressivos, como teremos oportunidade de verificar, o papel desempenhado pela comparação na formulação dos preceitos dessas legislações relativos ao arbítrio judicial, e que atinge especial relêvo, quando confrontamos os textos dos Códigos Penais vigentes

8. Marc ANCEL, Les Codes Pénaux Européens, publié par le "Centre Français de Droit Comparé", Tomo I, p. $\mathbf{x}$.

9. "Apud" HaROLdo VALADÃo, O Direito Latino-Americano, na Revista Jurídica, Pôrto Alegre, Vol. 12, 1954, p. 27. 
na Argentina e no México. Os dispositivos da lei mexicana que disciplinam a individualização da pena (art. 52) nada mais são do que meras cópias das disposições equivalentes no Direito argentino (art. 41).

Radl Carranca y Trujillo, estudando os pontos de contacto existentes nas codificações penais dêsses dois países, conclui por afirmar que o art. 52 da lei penal mexicana "es él mejor ejemplo de institución extranjera trasplantada al Derecho Patrio por via del Comparado", pôsto que "es reproducción fiel, salvo una que otra palabra o frase metamorfoseadas, del artículo 41, del Código Penal argentino"10.

De outra parte, o instituto da medida de segurança, também ligado ao problema da individualização na aplicação das sanções, reflete, por igual, o papel saliente atribuído à comparação nos domínios do Direito Penal. O Código de Costa Rica, o mais recente de tôda a América Latina, copiou boa parcela dos preceitos dos Códigos brasileiro e cubano, no que se refere àquele tipo de sanção penal.

II.

0 instituto da individualização da pena.

6. O problema da aplicação das sanções penais está na cúpula de todo o Direito repressivo. Intimamente ligado a êle, e objetivando a adequação da pena tanto ao crime como ao criminoso, encontra-se um dos mais importantes e discutidos institutos do moderno Direito Penal, o da individualização da pena.

E verdade que, no século xviII, já encontramos uma individualização a disciplinar a tarefa do julgador. Mas esta era, na realidade, uma "individualização social" das medidas repressivas, visto que deveriam ser aplicadas sem

10. Raul Carrancá y Trujillo, Teoria del Juez Penal Mexicano, em “Três Ensayos", México, 1944, p. 16. 
qualquer preocupação com as condições psicofísicas do delinqüente, e sim na conformidade com a posição dêste no seio de seu grupo. "Reconhecia-se a desigualdade dos individuos - observa Pedro Vergara - mas era uma desigualdade exterior, formada pelas diversas categorias sociais, e não uma desigualdade de índole, de caráter, de educação, de inteligência, em suma, de capacidade de delinqüir e de emendar-se"11.

No Livro v das Ordenações do Reino de Portugal, que vigorou no Brasil como lei penal até a promulgação do Código Criminal de 1830, encontramos exemplos os mais expressivos dessa odiosa política criminal. A título de ilustração, citemos êste: "Mandamos, que o homem, que dormir com mulher casada, e que em fama de casada estiver, morra por ello. Porém, se o adultero fosse Fidalgo, e o marido Cavalleiro, ou Scudeiro, ou adultero Cavalleiro, ou Scudeiro, e o marido peão, não farão as Justiçaś nelle execução, até nol-o fazerem saber, e verem sobre isso nosso mandado" ('Título xxv).

No início do século passado, entretanto, ao influxo das idéias vencedoras com a Revolução Francesa, e a conseqüente declaração da igualdade de todos perante a lei, passou-se, em matéria penal, a legislar em sentido opôsto. A defesa das liberdades individuais promovia o rompimento com a tradição do Direito medieval e o arbítrio judicial era erigido à categoria de algo nefasto na perfeita distribuição da justiça. "Para evitar todo e qualquer personalismo ensina o Prof. NoÉ Azevedo - constituiu-se um Direito Penal puramente objetivo. Os seus aplicadores não deveriam preocupar-se com a condição dos delinqüentes e sim com o fato e tôdas as suas circunstâncias. Assim se transformaram os crimes em verdadeiras entidades jurídicas. $O$ juiz julgava o delito e não o delinqüente" ${ }^{12}$.

11. Penro Vergara, Das Penas Principais e sua Aplicação, Rio, 1948 , p. 250.

12. NOÉ AZEVEDO, ob. cit., p. 113. 
O reexame de tal situação não tardou a preocupar os penalistas. Por volta de 1870 , a Escola Positiva passou a comandar a reação. A finalidade principal da pena se deslocaria da idéia de castigo para a de reeducação do delinqüente. Em vez de proporcionada ao mal do crime, condicionada à recuperação daquele que lhe deu causa. "Primeiro o homem, depois o delito", segundo a fórmula defendida por Ferri.

$O$ fundamento do direito de punir fugindo, assim, à proporção apriorística entre o mal do crime e o mal da pena, dava ensêjo à reformulação de todos os critérios vigorantes na aplicação das medidas repressivas. "Cuidouse, então, - ensina o Prof. Basileu Garcia - de atender às condições particulares do criminoso, à sua individualidade física, antropológica, moral. Alastrou-se a convicção de que o juiz deveria ter poderes para individualizar as sanções, considerando o delinqüente como uma realidade viva"13. Era a volta ao arbítrio judicial na cominação das penas, porém sem o personalismo odioso que o caracterizava no passado, mas, retemperado à luz das modernas conquistas da ciência penal, como instrumento poderoso a impulsionar as mais avançadas codificações.

7. Segundo a clássica divisão de SAleilles ${ }^{14}$, a individualização da pena se desenvolve, ou deve desenvolver-se, em três planos: o legal, o judicial e o administrativo. Alguns códigos chegam a mencionar expressamente a necessidade de encarar-se o problema da individualização das sanções sob êsse triplo aspecto, como acontece com o do Uruguai, conforme se lê em sua Exposição de motivos.

A individualização legal da pena, preleciona o Prof. Frederico Marques, é "a que o legislador estabelece quando discrimina as sanções cabíveis, delimita as espécies deli-

13. Basileu Garcia, Iinstituições de Direito Penal, Vol. I, Tomo II, 3. ${ }^{2}$ Ed., S. Paulo, 1956, p. 462.

14. Raymond Saleilles, L'Individualisation de la Peine, 3. ${ }^{\mathrm{a}} \mathrm{Ed}$, Paris, 1927, p. 12. 
tuosas e formula o preceito sancionador das normas incriminadoras ligando a cada um dos fatos típicos uma pena que varia entre um mínimo e um máximo claramente determinado"15.

Na opinião do próprio Saleilles, uma pura individualização legal não pode existir na realidade, com o que concorda SolER, ao afirmar que "tiene valor muy relativo la frase individualización legislativa", pois "la ley, claro está, debe conservar siempre su carácter de principio abstracto y genérico, y siendo así, não puede ir más allá de separar genéricamente categorias de hechos y de sujetos"16.

Para contornar a situação, o professor cubano ARMando M. RagGi Y Ageo propõe, como mais viável, o sistema que denomina de "organização legal da individualização judicial", visto que "la ley no suministra más que elementos de apreciación y sus bases muy amplias, dejando ao juez el cuidado de hacer un estudio especial de cada individuo"17

São, pois, na lei, elementos individualizadores aquêles que, não obstante correspondam a um mesmo fato delituoso, determinam conseqüências distintas, segundo o sujeito que o haja cometido.

Esta forma de individualização, que é feita sempre em abstrato, assume, entretanto, contornos mais expressivos em certos casos, como, por exemplo, quando o legislador autoriza a concessão da suspensão condicional da pena de reclusão ao condenado menor de vinte e um anos ou maior de setenta, se a condenação não fôr por prazo superior a dois anos.

A individualização legal absoluta, tão ao sabor dos códigos de inspiração clássica, com as penas tarifadas e apriorìsticamente previstas para cada caso possível, não

15. José Frederico Marques, Curso de Direito Penal, Vol. III, S. Paulo, 1956, p. 236.

16. Sebastian Soler, Derecho Penal Argentino, Tomo II, Buenos Aires, 1951, p. 470.

17. Armando M. Raggi y Ageo, Derecho Penal Cubano, $1 .^{\circ}$ Vol., Havana, 1938, p. 187. 
corresponde à moderna orientação do Direito Penal, e, por isso, vem sendo, a pouco e pouco, banida das diversas codificações, que pretendem, na cominação das sanções, colocar em igual nível tanto o delito como o delinqüente.

8. O legislador deve oferecer os critérios gerais, deixando ao juiz, com seu prudente arbítrio, a tarefa principal de aplicar a pena em concreto, atendendo às condições especialíssimas de cada caso. Nisto consiste a individualização judicial da pena.

O mesmo delito não é cometido de forma idêntica por dois sujeitos distintos, em oportunidades diversas. Em todos os casos, variarão não só o móvel do crime, como também os antecedentes pessoais, o estado de saúde, a situação econômica, etc., mesmo que os efeitos de ambos, objetivamente, sejam semelhantes.

A individualização da pena, por isso, explica o Prof. Frederico Marques, "tem de ser equacionada de maneira integral, de forma a compreender em seu âmbito o aspecto objetivo do crime, como fato violador de um bem jurídico penalmente tutelado, e a pessoa do delinqüente"18. Sòmente nessas condições será possível a realização de uma perfeita justiça criminal, ou seja, a de "retribuir o mal concreto do crime com o mal concreto da pena, na concreta personalidade do criminoso", segundo a fórmula defendida por NÉlson HunGria ${ }^{19}$.

A personalidade do delinqüente há de ser um dado básico para a individualização da pena. Todavia, a livre convicção do julgador não pode fixar-se de modo exclusivo nos elementos biopsíquicos da pessoa humana. $O$ órgão judicante, numa síntese tão difícil quanto necessária, deve fazer a justa adequação dêsses requisitos à situação de fato do crime, tendo em conta, ainda, os motivos e as diversas circunstâncias peculiares a cada caso em concreto.

18. José Frederico Marques, ob. cit., p. 235.

19. NÉlsoN HUNGRIA, $O$ arbitrio judicial na medida da pena, na "Revista Forense", Vol. LXXxIx, Rio, 1942, p. 5. 
Nessas condições, a tarefa do juiz se reveste da maior importância no Direito Penal moderno. “Já não será um intérprete escolástico da lei, um aplicador da justiça tarifada, um órgão de pronunciamento automático de fórmulas sacramentais - como observa Nélson Hungria -, mas uma consciência livre a regular direitos" ${ }^{20}$. Por isso, a responsabilidade do juiz, adverte, por seu turno, Ravl Barbosa, "multiplicou-se na mesma proporção em que se lhe conferiu o arbítrio. A investigação judiciária deve ser minuciosa, colhendo todos os elementos informativos relacionados com o crime e o criminoso" 21 .

9. A individualização administrativa é a que se dả na fase de cumprimento da pena imposta pelo magistrado. $\mathrm{Na}$ opinião de Siracusa ${ }^{22}$, é nessa oportunidade que o princípio da individualização da pena se revela como admirável conquista da legislação moderna.

É sob as vistas da administração carcerária que a personalidade do delinqüente vai mostrar-se em tôdas as suas mínimas facetas, muitas das quais podem ter fugido à percepção do próprio julgador. Nesse sentido, observa Sar.enlees ${ }^{23}$ que a individualização judicial não passa de um diagnóstico, pôsto que o remédio será dado pela administração penitenciária, à qual se deve conferir certa iniciativa.

İntimamente ligado ao problema da individualização administrativa da pena está o da sentença indeterminada, que é acolhida, entre outros, por Saleilles e Asúa. Consiste em negar ao juiz a faculdade de fixar "a priori" a duração da pena, cabendo a êle, tão-sòmente, declarar a culpabilidade do acusado, mandando-o à prisão. A duração da pena

20. NÉlson Hungria, art. cit., p. 10.

21. Raul Barbosa, $A$ individualização da pena no Código Penal, em "Direito", Ano IV, Vol. XxiIr, p. 106 e 107.

22. Francesco Siracusa, Istituzioni di Diritto Penintenziario, Milão, 1935, p. 109.

23. RAYMOND SAleilles, ob. cit., p. 134 e 346. 
ficará a critério da administração penitenciária, que a fará cessar desde que se torne supérflua.

Paul Cuche ${ }^{24}$ entende que a sentença indeterminada é a própria individualização administrativa da pena, pois, repetindo ensinamento de Saleilles, considera que na indeterminação da pena está a sua verdadeira individualização.

Segundo ainda CucHE, a origem da sentença indeterminada prende-se a velhas organizações religiosas, visto que certos tribunais eclesiásticos impunham condenações à prisão com duração indeterminada, até que o culpado manifestasse arrependimento. Nos tempos atuais, explica Batista de Melo que a indeterminação da pena "é novidade criada pela Escola Positiva"25. No Direito Penal comum, seu mais antigo defensor foi RoEDER, na Alemanha, que, em obra publicada em 1839, lançara o germe da sentença indeterminada, embora não tivesse usado a expressão hoje consagrada, de acôrdo com a lição do Prof. Basileu Garcia ${ }^{26}$. Mas seu verdadeiro idealizador e aplicador, com as características de que se reveste atualmente, foi Zacharias $R$. Brockway, o qual, em 1860, como diretor da "Casa de Correção de Detroit", induzira a Assembléia Legislativa de Michigan a votar a primeira lei instituindo a sentença indeterminada, que, ao depois, seria aplicada com inteiro êxito no reformatório modêlo de Elmira.

Todavia, mesmo sem a sentença indeterminada, a individualização administrativa pode perfeitamente realizar-se através de decisões complementares permissíveis na maioria das legislações modernas, na fase executória da pena, e consistentes nos institutos do "sursis", do livramento condicional e do perdão judicial, além da indulgência soberana. As medidas de segurança, por seu turno, sujeitas à fiscalização judicial tanto no decorrer do prazo mínimo com que

24. Paul Cuche, Traité de Science et de Législation Pénitenciaire, Paris, 1905, p. 27.

25. BATISTA DE Melo, Das Sentenças Indeterminadas, na "Revista dos Tribunais", Vol. 100, p. 8.

26. Basileu Garcia, ob. cit., Tomo I, p. 71. 
são cominadas, como também ao término dêste, e que podem, ainda, ser aplicadas por decisão proferida durante o cumprimento da pena, constituem remédio salutar no tratamento penitenciário do delinqüente.

Nestas condições, estamos de acôrdo com o Prof. Frederico Maroues, quando afirma que "a finalidade individualizadora que se pretende conseguir com a sentença indeterminada, para submeter-se o condenado ao tratamento penal exigido pelas suas condições pessoais, é obtida, com melhores resultados e de maneira mais completa e racional, com as medidas de segurança. A indeterminação do prazo dessas providências penais destinadas sobretudo à prevenção especial, realiza o escôpo da sentença indeterminada sem prejudicar os fins retributivos das sanções penais, uma vez que são cumpridas depois de executada a pena e enquanto perdurar o estado perigoso do delinqüente"27.

\section{III.}

\section{A individualização judicial da pena no Direito Penal Comparado latino-americano.}

10. Sendo, como é, o arbítrio judicial o pressuposto fundamental da individualização da pena, cuidaremos, em primeiro lugar, neste capítulo, das codificações latinoamericanas que concedem boa margem de liberdade ao juiz na cominação das sanções. São poucas e constituem boa parte das que, nos últimos tempos, experimentaram amplas reformas em sua estrutura, ajustando-se às modernas conquistas do Direito Penal.

Nos capítulos seguintes, trataremos, em linhas gerais, das legislações que ainda se apegam a uma rigida individualização legal, e, a final, procuraremos surpreender nos diversos códigos da América Latina os dispositivos que

27. José Frederico Marques, ob. cit., p. 241 e 242. 
pretendem realizar a individualização administrativa da pena ou que se liguem, por esta ou aquela maneira, às exigências dêste instituto.

\section{Argentina.}

11. O Código Penal argentino, promulgado em 29 de outubro de 1921, e em vigor a partir de 29 de abril de 1922, fundamentou-se, em suas linhas gerais, no Projeto Rodolfo Moreno, elaborado em 1917.

Num país onde a instabilidade legislativa é das mais notórias, êsse diploma repressivo vem resistindo galhardamente às várias tentativas de reforma, que começaram a surgir dois anos após sua promulgação. Sua aparição quase que simultânea com o Projeto Ferri de 1921 e a orientação nìtidamente positivista predominante nas cátedras das universidades argentinas, propiciaram, desde logo, a eclosão de um movimento reformista, através dos chamados "proyectos de estado peligroso", de 1924, 1926, 1928 e 1930, que não lograram, todavia, nenhum êxito. Efetivamente, uma das críticas que mais freqüentemente se faz à lei penal de 1922 é a de que, sendo um código moderno, consagra apenas tímida e prudentemente o problema da periculosidade, sem acolher, talvez por isso mesmo, as medidas de segurança.

A aplicação das sanções penais se distribui no Código argentino através dos artigos $35,37,40,41,44$ a 48 e 50 a 58 , enquanto que a individualização judicial da pena tem seu assento nos artigos 40 e 41, que são unânimemente considerados os textos básicos da lei.

Diz o artigo 40: "En las penas divisibles por razón de tiempo o de cantidad, los tribunales fijarán la condenación de acuerdo con las circunstancias atenuantes o agravantes particulares a cada caso y de conformidad a las reglas del artículo siguiente."

E o artigo 41: "A los efectos del artículo anterior, se tendrá en cuenta: 
$1 .^{\circ}$ - La natureza de la acción y de los medios empleados para ejecutarla y la extensión del daño y del peligro causados.

2. ${ }^{\circ}$ - La edad, la educación, las costumbres y la conducta precedente del sujeto, la calidad de los motivos que lo determinaron a delinquir, especialmente la miseria o la dificuldad de ganarse el sustento proprio necesario y el de los suyos, la participación que haya tomado en el hecho, las reincidencias en que hubiera incurrido y los demás antecedentes y condiciones personales, así como los vínculos personales, la calidad de las personas $\mathrm{y}$ las circunstancias de tiempo, lugar, modo y ocasión que demuestren su mayor o menor peligrosidad. El juez deberá tomar conocimiento directo y de visu del sujeto, de la víctima e de las circunstancias del hecho en la medida requerida para cada caso".

Como se vê pela simples leitura dêsses dispositivos, a individualização judicial da pena foi amplamente acolhida pelo legislador argentino, traduzida no expressivo arbítrio concedido ao juiz, o que levou o jurista patrício Raul BARBosa a afirmar que, "nesse sistema, o arbitrio judicial só encontra limite na cominação legal da pena. É a preeminência do arbítrio judicial"'28.

Soler observa que, da análise do texto individualizador, se conclui que "la adaptación de la pena se produce, pues, por medio de un doble proceso en el cual se aprecian, primero, los aspectos objetivos del hecho mesmo; depués, las circunstancias, las calidades del autor $y$, entre éstas, debe, incluirse las circunstancias de las que pueda inducirse un criterio acerca de la probabilidad de que el sujeto vuelva o no a delinquir" 29 .

No art. 40, estabelece o legislador argentino que a fixação da pena deverá atender às circunstâncias atenuantes ou agravantes próprias de cada caso, remetendo, em seguida, ao art. 41, que lhe dá a necessária complementação.

28. RAUL BARBOSA, art. cit., p. 112.

29. Sebastian Soler, ob. cit., p. 474. 
Observa-se, desde logo, que o Código argentino não segue o sistema geralmente adotado pela maioria das codificações contemporâneas, pois não consagra em artigos próprios as enumerações especificativas de circunstâncias atenuantes e agravantes, preferindo a forma ampla e menos casuística dos mencionados dispositivos.

Mario M. Mallo, acolhendo observações de Eusebio Gómez, entende que "las disposiciones sobre agravantes y atenuantes consagradas en nuestra ley con la amplitud que hemos visto constituyen el mayor acierto del legislador argentino, pues permite aproximarse al ideal de la adaptación de la pena al delincuente" 30 .

$\mathrm{O}$ art. 41 contém incisos que correspondem, respectivamente, à natureza do ato delituoso, à personalidade do delinqüente, às condições do ambiente social e familiar em que vivia o sujeito ao cometer a infração, bem como a maneira pela qual o órgão judicante deve apreciar os elementos ohjetivos e subjetivos do evento danoso. Com esta virtude, a primeira parte se ocupa da natureza da ação (não se refere à omissão, como o faz o artigo correspondente no Código mexicano) e dos meios utilizados para a sua execução, bem como dos resultados advindos do ato delituoso. A segunda parte reúne uma série de condições ligadas à pessoa do autor do delito (sem fazer alusão ao sexo, como julgam preferível alguns autores) e às circunstâncias que determinaram o ato danoso, terminando por rexigir do juiz que tome conhecimento direto e de viso (esbôço do princípio da identidade física do juiz) das pessoas que participaram da ação e das demais circunstâncias, de acôrdo com cada caso, a fim de que sua convicção não se forme apenas através das páginas do processo.

A redação dada aos questionados artigos não tem escapado à crítica de alguns penalistas mais exigentes. RauL Carrancá y Trujillo, professor mexicano, entre outros, entende que "el artículo 41 del Código Penal argentino, no

30. Mario M. Mallo, Código Penal Argentino Comentado, Tomo I, Buenos Aires, 1948, p. 272. 
obstante sus indudables aciertos, no es un modelo imposible de superar. Se advierten en él materiales dispersos sin ordenación ni sistema internos; a veces hasta gruesas impropriedades del lenguaje que son como actos fallidos por los que se denuncia todo un régimen social: así cuando se habla de la "calidad" de las personas, palabra emparentada con la idea de dignidad, nobleza y aristocracia de sangue" 31 .

A individualização da pena de multa é prevista no art. 21 da lei penal argentina, devendo o juiz estabelecer a maneira pela qual o condenado deverá pagá-la, tendo em conta sempre a sua situação econômica.

12. A individualização judicial da pena tal como foi acolhida pelo Código Penal da Argentina tem sido objeto de várias objeções, algumas, aliás, bem severas.

Dentre os comentadores dessa lei, destaca-se pelo rigor com que apreciou suas inovações, principalmente em seus êrros e defeitos técnicos, o Prof. Juan P. Ramos, da Universidade de Buenos Aires. Em várias passagens de suas obras, o mestre argentino procura demonstrar que "es falso que el código se base realmente en el principio de la individualización de la pena"32. E pergunta, depois de citar os artigos 40 e 41: "Como se puede individualizar todo eso con dos penas que siempre fueron una sola en el fondo? Como se puede individualizar la pena de los más peligrosos delincuentes contra la propriedad, si en todos los delitos contra la propriedad no hay más que una sola pena, la de prisión? Como se puede individualizar la pena en estos delitos que son los más abundantes en un pais moderno, si el código de 1922 no tiene sino los mismos máximos y mínimos de penas que el código que derogó?" E prossegue nesse diapasão, para, ao depois, perguntar: "Donde está, pues,

31. Raul Carrancá y TRUjillo, art. cit., p. 18.

32. JuAN P. Ramos, Curso de derecho penal, 2. ${ }^{\text {a }}$ Parte, Tomo IV, Buenos Aires, 1937, p. 85 e segs. e "Errores y Defectos Técnicos del Código Penal, na Revista de Psiquiatria y Criminologia, Buenos Aires, 1936. 
la individualización de la pena?", e, a final, responder: "En las palabras de la exposición de motivos. Pero no en la realidad del código ni en la realidad de su aplicación"33.

O Prof. Basileu Garcia, apreciando as objeções formuladas por JunN P. Ramos à lei penal argentina, as julga de inteira procedência, pois considera que "o legislador não procurou ajudar o juiz a lidar com as circunstâncias apúradas em cada caso. Influenciado em demasia pelos sarcasmos da Escola Positiva à dosimetria penal, deliberou extremadamente suprimi-la, esquecido de que a medida e a proporção também servem para o equilíbrio da justiça"34.

Entendemos nós que, se o dispositivo individualizador não está em. perfeita sintonia com a estrutura geral do Código, isso se deve atribuir ao fato de que o estatuto penal de 1922 representa um brusco rompimento com um longo passado vivido sob a influência direta dos penalistas da Escola Clássica. Sendo, como é, uma lei de transição, teria fatalmente que sofrer as conseqüências das inovações que acolheu.

Tais falhas, entretanto, não são de molde a comprometer todo o sistema do código, visto que tem merecido expressivos encômios de juristas do porte de Eusebio Gómez, Saldaña e Asúa. Êste último considera mesmo que o dispositivo individualizador "es donde el Código argentino ha logrado mayores aciertos, mereciendo plácemes superlativos" $" 35$.

Para conjurar êsses e outros inconvenientes de seu Código, dispõe a nação argentina de um notável estudo de lei repressiva, onde o equilíbrio de seus dispositivos supera tudo quanto já se programou, naquele país, em matéria

33. JUAN P. RAMOS, art. cit., p. 242 e 243.

34. BASILEU Garcia, Soluções penais da repressão ao crime de morte, tese, S. Paulo, 1938, p. 95.

35. "Apud" Basileu Garcia, Soluções penais da repressão ao crime de morte, p. 95. 
penal. Trata-se do "Anteproyecto Soler" que, remetido ao Congresso argentino em 1960, lá permanece esquecido, aguardando que o legislador se disponha a examiná-lo, antes que o govêrno, como sóe acontecer nesta região das Américas, acabe por "encomendar" outro "projeto" para a Argentina.

\section{Brasil.}

13. O Código Penal do Brasil, promulgado em 7 de dezembro de 1940 e em vigor a partir de 1 de janeiro de 1942, baseou-se no Projeto Alcântara Machado, que recebeu substanciais modificações através da comissão revisora. É um diploma de posição eclética, o que se depreende da própria Exposição de motivos, na qual se afirma expressamente que "nele os postulados clássicos fazem causa comum com os princípios da Escola Positiva".

Se tem, na verdade, indiscutíveis méritos, o Código de 1940, por outro lado, apresenta não poucos defeitos, que impossibilitam seja considerado uma lei à altura das melhores tradições do Direito brasileiro.

Em nosso país, o instituto da individualização da pena mereceu acolhida não só das leis penais em vigor como também da própria Carta Magna. O Código Penal de 1940 jnscreveu-o entre suas mais importantes inovações, através de seu art. 42, que concede razoável arbítrio ao juiz na cominação das sanções; o Código Penal Militar de 1944 nada mais fêz do que repetir em seu art. 57 as mesmas disposições daquele artigo da lei penal comum; e a Constituição Federal de 1946, por fim, contemplou a individualização da pena, em seu art. 141, $\S 29$, entre os direitos e garantias individuais, ao preceituar: "A lei penal regulará a individualização da pena e só retroagirá quando beneficiar o réu".

Por outro lado, objetivando a aplicabilidade do art. 42, nosso Código de Processo Penal, em complemento, no seu art. 157, acolheu o princípio da "livre convicção" do órgão 
judicante no manejo das provas, enquanto que a jurisprudência dos nossos tribunais já tem decidido pela anulação de processos em que se nâo faz a necessária individualização da pena (Sup. Trib. Federal, Acórdão de 11-6-1956, no H. C. 32.055, entre outros).

São êsses os recursos de que dispõe o instituto da individualização da pena entre nós, para proporcionar uma justa e acertada orientação na aplicação das sanções penais.

14. A introdução da individualização judicial da pena no atual Código Penal brasileiro foi saudada pelo nosso mundo jurídico como sua maior conquista, ao lado das medidas de segurança. RoBerto Lyra considera mesmo o art. 42 como "o mais importante do Código, não só pela decisiva influência de sua aplicação na defesa social e na tutela individual, como também pela conquista em que importa para a evolução do nosso Direito Penal"36. Outra não foi a opinião do Prof. Basileu Garcia, quando no $1 .^{\circ}$ Congresso Nacional do Ministério Público, reunido em S. Paulo, logo após o início da vigência de nosso estatuto penal, se discutia o dispositivo individualizador: "Na verdade, não há problema mais importante para o Código Penal brasileiro de 1940. Foi sob a bandeira da individuaIização da pena que êsse estatuto criminal apareceu em nosso cenário jurídico como um dos mais adiantados. Foi defendendo êsse princípio, pelo qual tanto propugnaram os escritores positivistas, que especialmente se firmou o prestígio do nosso Código Penal"37.

No mesmo sentido, a manifestação de outras ilustres expressões de nossa cultura juridica, e mesmo do exterior.

Diz o ari. 42: "Compete ao juiz, atendendo aos antecedentes e à personalidade do agente, à intensidade do dolo

36. Roberto Lyra, Comentários ao Código Penal, Vol. II, 2. a Ed., Rio, 1955, p. 187.

37. Anais do $1 .^{\circ}$ Congresso Nacional do Ministério Público, $20^{\circ}$ Vol., S. Paulo, 1943, p. 248. 
ou grau da culpa, aos motivos, às circunstâncias e conseqüências do crime: I - determinar a pena aplicável, dentre as cominadas alternativamente; II - fixar, dentro dos limites legais, a quantidade da pena aplicável".

Mais sóbrio e menos casuístico que a maioria dos dispositivos que disciplinam a matéria em outras codificações, pois o nosso Código contempla, ao depois, em artigos próprios, os elencos de circunstâncias atenuantes e agravantes, o critério individualizador do mencionado artigo, como assinala Nélson HUNGRIA, "não proclamou o puro arbitrio do juiz. Ficou a meio caminho entre os dois sistemas opostos, o da liberdade máxima e o da legalidade rígida" ${ }^{38}$. Preferiu o regime da cominação relativamente determinada, no qual são fixados os limites de quantidade e qualidade, dentro dos quais o juiz dosará convenientemente a pena a ser aplicada em cada caso em concreto.

$\mathrm{O}$ art. 42 contém os elementos subjetivos e objetivos com os quais o juiz deve regular seu arbitrio. Antes de tudo, necessita atender aos antecedentes e à personalidade do autor, pois "o delinqüente - adverte o Prof. NoÉ Azevedo, acolhendo pensamento de Spalding e Barrows deve ser encarcerado não pelo que fêz, mas pelo que é" 39 .

A vida pregressa e o conjunto dos fatôres biopsíquicos que compõem sua personalidade, segundo RoBErTo Lyra, devem ser atendidos "no sentido mais amplo, mais denso e mais profundo", pois o juiz deve ver sempre "que, se o julgamento se baseia no passado, a pena visa ao futuro" 40 . Por isso mesmo, ao fazer o levantamento da vida anterior do réu não deve o juiz limitar-se à verificação dos antecedentes judiciais ou policiais, aos processos ou às condenações anteriores. A expressão "antecedentes" contida no art. 42 tem de ser entendida no seu sentido mais amplo,

38. NÉlsON HUNGRIA, art. cit., p. 7.

39. Nó́ Azevedo, O Novo Projeto do Código Penal, na "Revista dos Tribunais", Vol. 64, 1927, p. 7.

40. ROBERTO LYRA, ob. cit., p. 215 e 216. 
incluindo - o que, infelizmente, não tem sido levado na devida consideração entre nós - a pesquisa e a análise da vida familiar, econômica, profissional e social do delinqüente.

Refere-se a lei, em seguida, à intensidade do dolo ou ao grau da culpa, como elementos sujeitos à avaliação do juiz. Distingue-se, na doutrina, o dolo de ímpeto do dolo premeditado, sendo aquêle menos grave que êste. O Código entretanto, não contemplou a premeditação no rol das circunstâncias agravantes, o que não impede que seja levada em conta pelo órgão judicante, integrando-a nas disposições do art. 42, como forma reveladora de maior intensidade do dolo, conforme consenso geral.

Alude, ainda, o Código aos motivos, às circunstâncias e conseqüências do crime. $\mathrm{O}$ motivo, elemento indicador da maior ou menor periculosidade do agente, dado que, consoante observa Magalhães Noronha, "a gravidade do crime reside principalmente nele, pois tem o condão de transformar um delito execrável em tolerado"41, tem, depois, suas formas mais graves relacionadas entre as circunstâncias agravantes.

As circunstâncias em seus vários matizes, compreendendo o tempo, o lugar, os meios empregados, a maneira de agir, etc., são também elementos de relevância para a aferição da gravidade do delito. Neste particular, divergem os comentadores do Código de 1940. Enquanto que para uns as circunstâncias previstas no art. 42 são apenas as judiciais, não inoluindo as contempladas nos arts. 44 a 48 , outros entendem que as chamadas circunstâncias legais também ali se compreendem.

Por fim, o julgador deve atender às conseqüências do ato criminoso, através da gravidade do dano ou perigo de dano, não só em relação à vítima, como também com referência à sociedade, ao ambiente em que se desenvalve.

41. Edgard Magalhães Noronha, Direito Penal, $10^{\circ}$ Vol., S. Paulo, 1959 , p. 316. 
Ressalvada a primazia dos elementos de índole subjetiva (art. 49), o exame de todos êsses elementos deve ser unitário, pois o juiz não pode dar mais ênfase a alguns em detrimento de outros, no cumprimento de sua tarefa individualizadora.

A interpretação do Código em matéria de aplicação da pena não tem sido uniforme. Os autores divergem a respeito da ordem em que devem ser atendidos os elementos e circunstâncias do art. 42, no seu confronto com as circunstâncias chamadas legais, dos arts. 44 a 48 . O âmbito dêste trabalho, todavia, não comporta o exame dessas divergências.

No que respeita à pena de multa, o juiz não deve fugir ainda às disposições do art. 42, embora seja o artigo seguinte a sede da individualização da pena pecuniária. $O$ art. 43 determina que, na graduação desta pena, seja atendida a situação econômica do acusado, autorizando, entretanto, o juiz até a trỉplicar o máximo cominado, quando fôr insuficiente em relação às posses do réu.

15. A individualização judicial da pena, da maneira com que vem sendo praticada no Brasil, não tem correspondido aos aplausos com que sua inclusão em nosso estatuto repressivo foi recebida pelo mundo jurídico.

O Prof. Basileu Garcia, que, em sua tese de concurso, formulara votos no sentido de que "o nôvo Código Penal do Brasil não contribua para a insegurança da repressão criminal, que a tanto equivalerá a incerteza dos critérios de aplicação da pena"42, não pôde esconder, em suas "Instituições", publicadas quando o Código de 1940 já havia cumprido mais de 10 anos de existência, seu desencanto pelas soluções dadas na prática ao problema, diante da falta de aparelhamento material em apoio dos critérios legislativos. Afirma o mestre: "Substituimos, pois, o sis-

42. BASIleU GaRcia, Soluções penais da repressão ao crime de morte, p. 98 e 99 . 
tema legislativo, mas continuamos com as mesmas deficiências do tempo da Consolidação das Leis Penais. Criamos a função, sem ter o órgão, e, por isso, a função não opera. Assim, a individualização penal, em nosso meio, prossegue na ordem quase exclusivamente teórica. A imposição da pena, que deveria ser mais sábia, com o caráter científico suposto no Código, é tão-só mais incerta, mais variável, mais insegura, do que no mecanismo precedente" ${ }^{43}$.

Antônio de Brito Alves, em trabalho sugestivamente intitulado "Artigo 42, Esse Grande Desconhecido", alinha interessantes considerações em tôrno da orientação que se vem dando à aplicação do questionado artigo de nossa lei penal. "Entendemos — diz êle — que, em geral, não se tem dado ao art. 42 do Código Penal a especial relevância que êle possui na paisagem dos estudos penais modernos. $\mathrm{Na}$ melhor das hipóteses, a sua aplicação vem sendo feita apressada e defeituosamente, fato, sem dúvida, estranhíssimo se atentarmos para a circunstância de estar tôda a matéria da aplicação da pena subordinada aos critérios expressamente fixados no dispositivo em questão"44.

Efetivamente, sendo obra de juízes, pois dos quatro membros da comissão elaboradora três pertenciam à magistratura, era de esperar-se que os nossos julgadores atendessem melhor aos requisitos do art. 42 , diante de cada caso em especial. Tal, entretanto, não tem acontecido. Sem fazer uso dos poderes mais ou menos amplos que lhes foram concedidos, os magistrados brasileiros, ou por apêgo às regras do passado, ou por sentirem-se temerosos em fazer valer seu arbítrio, via de regra, escolhem as soluções mais brandas, desprezando as circunstàncias que ensejariam o agravamento da pena.

Em relação à pena pecuniária, observa-se o mesmo comportamento. Apesar de se acharem totalmente desatua-

43. Basileu Garcia, Instituições, Tomo II, p. 462 e 463.

44. Antônio de Brito Alves, Artigo 42, Êsse Grande Desconhecido, na "Revista Pernambucana de Direito Penal e Criminologia", N. ${ }^{\circ} 3,1954$, p. 213. 
lizadas, em face do ritmo inflacionário que vem destruindo progressivamente nossa moeda, as multas previstas no Código Penal são, quase sempre, cominadas em seu limite mínimo.

\section{Colômbia.}

16. O Código Penal da Colômbia foi sancionado em 24 de abril de 1936, tendo entrado em vigor a partir de 1 de janeiro de 1937. Com êle, que se prende ao Projeto de 1925, com dispositivos transcritos diretamente do Projeto Ferri de 1921, foi derrogado o velho estatuto penal de 1887, que vinha resistindo às várias tentativas de reforma.

A orientação dada à lei penal colombiana parece que também não correspondeu aos anseios dos juristas daquele país. Mário Garcia Herrero, um dos seus mais ilustres comentadores, entende mesmo que "el Código actual encarna una miscelánea de critérios que, por carecer de seguros e profundos basamentos filosóficos, ha dado lugar a que muchas de sus normas se presenten como secuela transactiva sin concierto alguno en vez de como definida resultante de unívoca conceptuación científica"45.

A aplicação das sanções penais ocupa os arts. 16 a 22, 27, 28, 31 a 34 e 36 a 40 . Acolhe também as medidas de segurança, mas em várias passagens comete lamentáveis erros técnicos, pois usa o têrmo pena ao referir-se àquelas providências.

A individualização judicial da pena tem acolhida no art. 36, que estatui: "Dentro de los limites señalados por la ley, se le aplicará la sanción al delincuente, según la gravedad y modalidades del hecho delictuoso, los motivos determinantes, las circunstancias de mayor o menor peligrosidad que lo acompañen y la personalidad del agente".

45. Mário Garcia Herrero, El Nuevo Código Penal Colombiano, na "Revista de Identificación y Ciencias Penales", Vol. 20, 1943, p. 313. 
Pedro Vergara ${ }^{46}$ considera o art. 36 do Código colombiano de uma sobriedade só comparável à do nosso estatuto penal, enquanto que os juristas daquele país alçam o dispositivo em questão à categoria de fundamental em sua lei.

Verifica-se, de pronto, a preocupação do legislador colombiano em circunscrever o arbítrio judicial aos limites legais, para, ao depois, cuidar do elemento objetivo e, finalmente, atender aos aspectos subjetivos do ato delituoso.

Não há opção qualitativa por parte do juiz na cominação da pena, mas tão-sòmente quantitativa, no que vai além do próprio Projeto Ferri. Tal restrição tem merecido algumas críticas, entre as quais as de Eduardo Fernandez Botero. Entende aquêle jurista que seria "el ideal de que Ia pena fuesse proporcionada en calidad y cantidad al delincuente mismo para que se produzcan los efectos en la relación con quién ha de ser sancionado $\mathrm{y}$ se diferencie a dos autores de un mismo hecho, así como el tratamiento médico diferencia dos organismos afectos del mismo mal"47.

A personalidade do delinqüente merece especial atenção do art. 36, no que é complementado pelos dispositivos seguintes que, em 28 alentados itens, cuidam das "circunstancias de mayor o menor peligrosidad". Já na Exposição de motivos se vê firmada essa orientação, ao justificar "la adopción de disposiciones que exijan el estudio del delincuente como personalidad antisocial y permitan la aplicación de las sanciones, teniendo en cuenta, principalmente, no solo la objetividad de los hechos considerada materialmente, sino los motivos determinantes, las circunstancias de mayor o menor peligrosidad de éste".

Quanto à pena de multa, dentro dos limites e condições prefixadas pelo art. 50, deverá ser "proporcionada a las

46. Pedro Vergara, ob. cit., p. 265.

47. Eduardo Fernandez Botero, Estudios sobre el Código Penal Colombiano, em "Estudios de Derecho", N.o 7, 1941, Medellin, p. 78. 
condiciones económicas del condenado y a la gravedad de la infracción".

17. Todavia, como sóe acontecer, a aplicabilidade do artigo individualizador não tem correspondido plenamente. A despeito de terem sido instituidos cursos de especialização jurídico-criminal " $\mathrm{y}$ establecer como requisito indispensable para poder desempeñar el cargo de Juez de Instrucción haber seguido y aprobado tales estudios", como nos dá conta Diego Montana Cuellan ${ }^{48}$, a magistratura daquele país não tem levado na devida consideração o mencionado dispositivo.

Mário Garcia Herrero, justificando o descaso dos juízes colombianos em relação ao art. 36 de sua lei penal, explica que a Colômbia "carece hasta ahora de los laboratórios necesarios y del personal técnico idóneo para la realización de tal estudio" indispensáveis para fornecer aos magistrados os elementos com que deverão julgar, e que "por otra parte, y aun cuando sea doloroso reconocerlo, el país no cuenta con una organización policiva técnica suficiente a llenar los requisitos que exige el inteligente y meditado proceso previo a que da lugar la aplicación práctica del Código de 1936". E conclui: "Por tanto, puede afirmarse que la realidad actual en cuanto a la aplicación del nuevo Código Penal se halla reducida a la continuación de los viejos sistemas penales frente a la teórica existência de las nuevas ideas"49.

Do mesmo entender é o Prof. Gutiérrez Anzola, quando afirma: "Tengo que concluir, aunque dolièndome de ello, que la reforma en general es sólo un romántico esfuerzo por la justicia, pero no una copia palpitante de la realidad colombiana" $"$.

48. Diego Montana Cuellar, La Reforma Penal en Colombia, em "Criminalia", 1941-1942, p. 549.

49. MÁrio Garcia HeRrero, art. cit., p. 313 e 314.

50. "Apud" Mário Garcia Herrero, art. cit., p. 314. 


\section{Cuba.}

18. Cuba foi o último dos paises hispano-americanos a derrogar a lei penal que fôra imposta pela Metrópole. Em 4 de abril de 1936, foi aprovado seu atual estatuto penal, o qual entrou em vigência sòmente em 9 de outubro de 1938.

A reforma foi quase radical, a começar pelo título dado ao nôvo diploma: Código de Defesa Social. Defendendo-se das objeções que a essa denominação formulara Asúa, JosÉ Agustín Martínez que, como membro da comissão elaboradora do projeto, sugerira e conseguira ver aprovado o nôvo rótulo do Código cubano, assim o justifica: "Es necesario que exista una lesión al interés social aunque sea mínimo, para que surja la figura característica del delito. En cuanto a la reacción que la sociedad ofrece a la agresión, no debe ser punitiva ni venir inspirada en un propósito arcaico de venganza. Debe ser puramente defensiva. Por eso preferimoa la denominación que en definitiva llegó a adoptarse por la reforma" 51 .

O Código Penal de Cuba é, realmente, inovador. Estende às pessoas jurídicas a responsabilidade na ordem criminal (art. 16), adota um conceito amplo de "estado peligroso", e consagra, entre outros princípios, o da "adecuación de la pena a la personalidad del delincuente", oferecendo amplo arbítrio ao juiz na cominação das sanções.

$\mathrm{O}$ art. 67 estabelece: "El tribunal, al dictar sentencia, fijará la medida de la sanción que estime justa, dentro de los limites establecidos por este Código para cada caso, conforme a su prudente arbitrio, apreciando las condiciones personales del delincuente, su mayor o menor peligrosidad, los móviles del delito y todas las circunstancias que concurrieren en el hecho, aun cuando estas últimas no se encuentren suficientemente caracterizadas para señalarlas como circunstancias modificativas de la responsabilidad".

51. José Agustín Martínez, Prólogo ao Derecho Penal Cubano, de Armando M. RAGGi y Ageo, p. 12. 
A aplicação das sanções penais se desenvolve, ainda, pelos artigos $23,24,30 \S$ último e 66 a 75 .

19. A adoção da individualização judicial da pena representa uma das mais efetivas reações do Código de 1936 à velha lei penal vigorante na ilha, que adotava "un sistema impenetrable, cerrado por completo al arbitrio judicial", com "fórmulas matemáticas inmutables, fundadas exclusivamente en el quantum del delito", conforme observa Armando M. Raggi y Ageo ${ }^{52}$.

O arbítrio judicial, com a amplitude com que foi acolhido pelo Código de 1936, atende às exigências de um estatuto de inspiração político-criminal. Pelo exame do art. 67, verifica-se que o juiz ao prolatar a sentença, deverá levar em consideração, não só o aspecto anti-jurídico do evento, sua qualidade, quantidade e circunstâncias objetivas, conforme o Código anterior, como também e imprescindivelmente: a) as condições pessoais do delinqüente, incluindo sua conduta social e familiar, meios de vida, etc.; b) seu grau de periculosidade, determinado não só pelas condições acima, como também pela sua constituição biopsíquica; c) os motivos determinantes do delito, com tôda a gama de requisitos que o elemento subjetivo pode carrear ao fato concreto; e d) tôdas as demais circunstâncias que possam ter concorrido para a prática do ato anti-social, mesmo aquelas que não disponham das características necessárias para alterar a responsabilidade do autor do delito. É, pois, dos mais extensos o quadro da livre determinação do juiz cubano, na formação de sua convicção diante de cada delito.

Morsés A. Vieites, todavia, contestou a orientação dada ao estatuto cubano, quando da discussão do projeto. Entendia êle que o Código deveria acolher normas mais de caráter protetor, do que defensivas. Na parte referente à individualização da pena, aconselhava "que al aplicarse el

52. Armando M. RagGi y AGEo, ob. cit., p. 227. 
arbitrio judicial de acuerdo con la peligrosidad del infractor debían suprimirse en la ley las circunstancias eximentes, agravantes e atenuantes, así como la distinción entre autores, cómplices, encubridores, tentativa, delito frustrado, etc." 53 . Todavia, em que pesem juízos discordantes, a lei penal cubana mereceu fartos elogios de eminentes penalistas, entre os quais se incluem Florian e Altavilla.

20. Entretanto, nos dias que correm, assiste-se em Cuba a uma total submissão do Poder Judiciário ao poder político, em face do regime ali vigorante, que as excelentes conquistas do Código de 1936 se reduzem a letra morta. Em trabalho recentemente publicado e em elaboração há mais de um ano, intitulado "Cuba e o Império da Lei", a Comissão Internacional de Juristas, órgão Consultivo da oNU, condena em têrmos veementes a situação reinante em Cuba. Depois de afirmar que "todo desenvolvimento deve ser perseguido e obtido através do Império da Lei e não por cima desta", diz o informe da Comissão: "As reformas sociais e econômicas exigem profundo respeito pelo Império da Lei e, quando criam nova ilegalidade, estão condenadas a provocar mais sofrimento e terminam em absoluto fracasso. A primeira fenda no cimento da liberdade, que não seja devidamente controlada, conduz, tarde ou cedo, à derrubada total do Império da Lei" ${ }^{54}$.

$\mathrm{O}$ arbítrio do juiz foi substituido pelo arbitrio do poder político, pois com a exacerbada competência atribuída aos tribunais revolucionários, a Justiça comum tornou-se inoperante, e um nôvo sistema de repressão penal está sendo pôsto em prática na ilha. A tradição de ordem e respeito à lei, que está no cerne do povo cubano, nos indica que, dentro em breve, o Império da Lei estará restabelecido em Cuba.

53. Morsés A. Vieites, Mi contribución al actual Proyecto de reforma penal en Cuba, Havana, 1935, p. 8.

54. Resumo publicado na Fôlha de S. Paulo, de 21 de novembro de 1962, 3.a Secção, p. 1. 


\section{México.}

21. O Código Penal mexicano foi promulgado em $\mathbf{1 3}$ de agôsto de 1931, não se tendo filiado com exclusividade a nenhuma escola ou sistema. É, por isso mesmo, eclético. Segundo o testemunho de Raul Carrancá y Trujillo, o estatuto penal mexicano inspirou-se, principalmente, nos tratadistas Luis Jiménez dE Asúa, Quintiliano Saldaña e EugÊnio Cuello Calón, embora seja fàcilmente reconhecível nêle boa parcela de influência do Direito argentino.

Em razão de dispositivo constitucional vigente no México, os 28 Estados que compõem a Federação passaram a legislar sôbre matéria penal, surgindo então diferentes estatutos penais. Êste sistema de multiplicidade de códigos é desaconselhável, e como tal vem sendo combatido pelos penalistas daquele país, que desejam a unificação de sua legislação repressiva, a exemplo do que se passou na Suíça, que, tendo deixado aos Cantões a tarefa de elaborar seus códigos, veio a pôr em vigor, em 1942, um Código Penal Federal.

Advirta-se, porém, que o Código de 1931 tem, na verdade, um caráter misto. É a lei penal oficial no Distrito Federal e nos dois territórios da União, mas também tem vigência em todos os Estados para os delitos que envolvam a administração pública federal. Entretanto, na sua íntegra, foi adotado em nada menos que 18 Estados da Federação mexicana.

O sistema de aplicação das penas no Código de 1931 espalha-se pelos artigos $12,13,51$ a 66 e 73 a 76 , enquanto que a individualização judicial da pena tem abrigo nos seguintes dispositivos:

Estabelece o art. 51 - "Dentro de los límites fijados por la ley, los jueces y tribunales aplicarán las sanciones establecidas para cada delito, teniendo en cuenta las circunstancias exteriores de ejecución y las peculiares del 
delincuente". E o art. 52, acrescenta: "En la aplicación de las sanciones penales se tendrá en cuenta: $10^{\circ}$ - La natureza de la acción o omisión y de los medios empleados para ejecutarla y la extensión del daño causado y del peligro corrido; $2^{\circ}$ - La edad, la educación, la ilustración, las costumbres y la conducta precedente del sujeto, los motivos que lo impulsaron o determinaron a delinquir y sus condiciones económicas; $3 .^{\circ}$ - Las condiciones especiales en que se encontraba en el momento de la comisión del delito y los demás antecedentes y condiciones personales que puedan comprobarse, así como sus vínculos de parentesco, de amistad o nacidos de otras relaciones sociales, la calidad de las personas ofendidas y las circunstancias de tiempo, lugar, modo y ocasión que demuestren su mayor o menor temibilidad.

El juez deberá tomar conocimiento directo del sujeto, de la victima y de las circunstancias del hecho en la medida requerida para cada caso".

Raul Carrancá y Trujillo considera o art. 52 o texto fundamental do Código de 1931, enquanto que José ANGEL Ceniceros, um dos membros da comissão redatora, julga que a "alma de la reforma penal es la ampliación del arbítrio judicial, con el convencimiento profundo de que con él se logra realizar una eficaz individualización de las penas" $" 55$.

Tendo-se filiado ao sistema argentino em matéria de aplicação da pena, o Código do México diverge, entretanto, em vários pontos, daquele estatuto penal. Assim é que, ao contrário do que se estatuiu na Argentina, acolhe as medidas de segurança, sem, todavia, dar-lhes muita amplitude, e estabelece diversa orientação não só na discriminação das sanções, como também na maneira de cominá-las. Segue, no entanto, o modêlo argentino ao limitar-se apenas às circunstâncias do dispositivo individualizador na aferição

55. José Anget Ceniceros, El Código Penal Mexicano, em "Homenage a Florian", México, 1940, p. 257. 
dos elementos concorrentes ao crime, sem reunir em artigos próprios as que determinariam a atenuação ou o agravamento da pena.

As disposições do art. 52 estabelecem, respectivamente, ao tipo de ato delituoso, especial atenção do julgador, enquanto que a personalidade do delinqüente e as condições familiares e sociais a êle ligadas lhe segue em importância. Fixa, em seguida, a maneira pela qual o magistrado deve apreciar os elementos objetivos e subjetivos do delito. Assim sendo, ocupa-se, de início, da natureza da ação, referindo-se, inclusive, à omissão, no que não seguiu o modêlo argentino, bem como dos meios empregados para a sua concretização e dos resultados do ato delituoso. Nos itens seguintes, trata das condições intrínsecas ligadas ao autor do ato, e das demais circunstâncias ligadas ao crime, terminando por exigir que tome conhecimento direto dos protagonistas e de tôdas as circunstâncias e elementos o juiz aplicador da pena. A parte final do dispositivo, que é uma tentativa para a adoção do princípio da identidade física do juiz, matéria de ordem processual, recebeu complementação através do Código de Procedimientos Penales. "Es el deseo del legislador - explica LuIs Garrido - que los jueces penales impartan justicia ya no desde un oscuro despacho, através de la lectura de las diligencias, sino que califiquen del delito y de la pena conseguiente, de acuerdo con el estudio personal del delincuente. Por eso nuestro Código de Procedimientos Penales fija que en todos los casos debe hacerse un estudio biopsiquico del delincuente"56.

Como sanções pecuniárias, estabelece o art. 29 do Código mexicano a multa e a reparação do dano. Aquela poderá ser substituída por dias de prisão, quando o condenado não puder pagá-la ou só puder pagá-la em parte. Na sua cominação, que não deve exceder de quatro meses, deverão ser levadas em consideração as condições econômicas do réu.

56. LUIS GARRID0, La Doctrina Mexicana de Nuestro Derecho Penal, em “Criminalia”, 1940-1941, p. 244. 
22. Sendo o art. 52 cópia de disposição equivalente no Código argentino, aplicam-se-lhe as críticas já reunidas em tôrno do art. 41 daquele código. Verifica-se, entretanto, que o legislador mexicano, alertado por aquelas referências à lei argentina, procurou dar uma redação mais precisa ao texto individualizador. É o que nos informa LuIS GarRIDo: "La Comisión tuvo conocimiento que eminentes profesores de la Universidad de Buenos Aires habían analizado con acritud aquella norma. Se le atacaba atribuyéndole imprecisión y falta de criterio. El profesor JuAN P. Ramos afirmó que no separa las cuestiones de una manera adecuada y que establece el criterio de la peligrosidad y no da a la justicia sino la pena dosificada como única sanción. Por eso, la Comisión, al conocer estas criticas, redactó el artículo 52 conforme a una forma más clara y más sistemática que el Código argentino" $" 57$.

Tais cuidados revelados pelo legislador mexicano, entretanto, como se vê do simples confronto dos textos das duas leis, não tiveram o mérito de tornar mais preciso o dispositivo individualizador do Código de 1931.

\section{Peru.}

23. O Código Penal do Peru, promulgado em 28 de julho de 1924, com vigência para o dia imediato, teve por base o Projeto Victor M. Maúrtua, apresentado em 1916, com as modificações introduzidas pela comissão revisora, designada em 1921.

Em sua promulgação, foi saudado pelo mundo jurídico como um dos mais avançados diplomas penais da atualidade. Penitenciando-se do falso juízo que fizera do Código, através da leitura de notícias esparsas publicadas em revista francesa, AsúA, quando da oportunidade de submetê-lo a exame, não teve dúvidas em afirmar que "el Código del

57. LUIS GARRID0, art. cit., p. 240. 
Perú puede figurar entre los más avanzados documentos: legislativos y es uno de los hechos más importantes de la legislación penal contemporânea"58.

No Brasil, particularmente, o Código teve ampla repercussão, divulgado que foi pelo próprio autor do projeto, pois, em 1924, MAƯRTUA exercia as funções de representante diplomático de seu país junto ao nosso govêrno.

Realmente, escrito em linguagem simples, sem definições ou preceitos filosóficos, o Código peruano em vigor é uma das mais avançadas leis repressivas de tôda a América, especialmente no capítulo referente à aplicação das penas.

$A$ individualização judicial da pena, sob a epígrafe de "aplicación judicial de las penas", é feita através dos seguintes dispositivos: Art. 50 — "Los jueces aplicarán la pena adoptando el máximum o el mínimum señalados por la ley para el delito o imponiendo entre los dos extremos la medida que creyren necesaria. Deberán expresar en la sentencia los motivos que aconsejen la medida que hubieren adoptado".

Art. 51 - "Para la aplicación de la pena los jueces apreciarán la culpabilidad y el peligro del agente, teniendoen cuenta las siguientes circunstancias, en cuanto la ley no: las considere especialmente como constitutivas o modificadoras del delito:

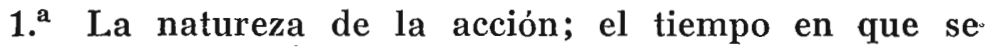
perpetró y el que hubiere trascurrido desde entonces; el lugar, los instrumentos y los medios de que se hubiere hecho uso; la preparación tranquila o la perpetración ocasional; el modo de ejecución y las circunstancias en que ésta se hubiere efectuado; la unidad o la pluralidad de agentes; eI número y la importancia o especialidad de los deberes infringidos; la dificuldad que hubiere para prevenirse contra el hecho punible; y la extensión del daño y del peligro causados.

58. Luis Jiménez de AsúA, El Derecho Penal en la Republica. del Peru, 1926, p. 58. 


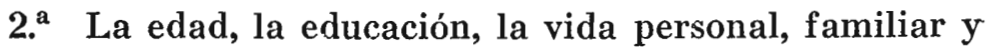
social del sujeto, anterior y posterior al delito, su situación económica, sus precedentes judiciales y penales, la calidad de los móviles honorables o excusables o innobles o fútiles que lo determinaron a delinquir, las emociones que lo hubieran agitado, su participación mayor o menor en el delito, la reparación espontánea que hubiere hecho del daño, o la confesión sincera antes de haber sido descubierto, y los demás antecedentes, condiciones personales y circunstancias que conduzcan al conocimiento de su carácter".

Pela simples leitura dêsses dispositivos, verifica-se que o Código do Peru pode ser considerado o mais minucioso, o mais casuístico, o mais circunstanciado de todos os estatutos da América Latina, em matéria de arbítrio judicial. Nada ou quase nada ficou por estatuir-se no art. 51, diante de acúmulo de elementos, de fatôres, de circunstâncias as mais diversas com que o legislador peruano dotou o artigo individualizador.

A faculdade do juiz na cominação da pena, dentro dos limites fixados pela lei para cada caso, consiste, primeiramente, na apreciação da culpabilidade e periculosidade do agente, em face de um conjunto de circunstâncias que incluem fatôres inerentes à ação, e mais o tempo, o lugar, o modo, os instrumentos, a premeditação (preparación tranquila), a forma de execução, a pluralidade ou não de agentes, os bens atingidos e o dano causado. Numa segunda etapa, o julgador deverá atender, na formação de seu convencimento, a uma série de fatôres diretamente ligados ao sujeito ativo da infração penal, que vão desde suas condições de educação, vida familiar, econômica, social, até os motivos determinantes diretamente do ato danoso que praticou.

Verifica-se, portanto, que o legislador peruano parece ter esgotado, nas minúcias com que dotou o art. 51, tudo quanto possa ligar-se à personalidade do delinqüente e ao complexo formado pelos demais elementos, tanto subjetivos como objetivos, do ato criminoso. 
24. A promulgação do Código de 1924, conforme salientámos, repercutiu favoràvelmente em tôda a América, e, particularmente, no Brasil. O jurista patrício Esmeraldino BANDEIra analisando o Código, no início de sua vigência, dizia que a leitura atenta de seu texto o levava "às três seguintes e máximas conclusões: $1 .^{a}$ ) que emancipou êle a mentalidade peruana da tutela póstuma de Carrara; $2 .^{a}$ ) que o Código tem potencialidade jurídica para viver muitos anos; $3 .^{\text {a) }}$ e que tem valor científico para servir de modêlo aos novos códigos" ${ }^{99}$. Quanto ao arbítrio judicial, com a amplitude com que foi acolhido, mostrou-se discreto em seu julgamento, preferindo aguardar que os fatos viessem a confirmar ou não os aplausos que o art. 51 merecera por tôda a parte.

Oscar Drumond Costa foi, todavia, mais incisivo: "O livre arbítrio judicial é o espírito vivificador do Código peruano"60.

Salientam, entretanto, os comentadores, que a magistratura peruana não acolheu com muito agrado o Código de 1924. Fiel aos postulados da Escola Clássica, mal entrou em vigor a nova lei penal, já constituiam os juízes daquele país uma comissão encarregada de reformá-la, principalmente por se oporem à adoção das medidas de segurança e à derrogação das antigas normas para a fixação das penas.

Asúa, manifestando-se, em obra especialmente dedicada ao estudo do Código do Peru, contrário à pretendida reforma, advertia: "Reformar el Código suprimiendo el arbitrio de los juezes y extirpando de él las medidas de seguridad, es método tan ingenuo como cortar un miembro para acallar el dolor". E, em seguida, concluia: "Yo me atrevería a aconsejar a los juristas peruanos que mantengan la integridad de su Código, y que orienten la reforma penal en el sentido de organizar una magistratura moderna,

59. Esmeraldino Bandeira, O Novo Código Penal do Peru, na “Revista do Supremo Tribunal”, Vol. 72, 1924, p. 759.

60. Oscar Drumond Costa, O Novo Código Penal Peruano, na “Revista dos Tribunais", Vol. 53, 1925, p. 125. 
formada en los conocimientos antroposociológicos y técnicojurídicos, y de fundar un sistema penitenciário científico actuado en establecimientos correccionales y bien dirigidos"61.

\section{Uruguai.}

25. O Código Penal uruguaio, em vigor a partir de $1 .^{\circ} \mathrm{de}$ janeiro de 1934, foi promulgado em 3 de maio de 1933. É o próprio "Projeto José Irureta Goyena" convertido em lei. Segue orientação político-criminal, com influência direta do Código italiano de 1930, embora mais democrata e liberal, em razão das idéias de seu autor.

Na Exposição de motivos, Goyena faz uma profecia que, todavia, não se cumpriu: "No me hago ilusiones acerca de la suerte que le está destinada. El Colégio (de Abogados) se ocupará de él; lo estudiará, lo perfeccionará, hará, en suma, todo lo indispensable para que el Parlamento lo transforme en Ley, pero el Parlamento lo dejará envejecer en las carpetas y cuando resuelva prestarle su atención ya no será digno de ella". Ao contrário de tudo isso, o Projeto, ràpidamente e sem emendas, foi aprovado e pôsto em vigência.

O estatuto penal uruguaio tem merecido também fartos elogios de categorizados comentadores. Florian ${ }^{62}$ dedicoulhe entusiásticas palavras; Asúa considerou-o tècnicamente correto, embora "se resienta, a veces, de excesivo teoricismo"63; enquanto que o penalista argentino JoRGE Éduardo Corll resumiu sua opinião, afirmando que "la ley uruguaya puede calificarse en la posición doctrinaria adoptada como

61. LUIS JiméNez DE AsÚA, El Derecho Penal en La Republica del Peru, p. 59.

62. "Apud" C. Salvagno Campos, Curso de Derecho Penal, Vol. I, Montevidéu, 1941, p. 11.

63. LuIs Jiménez DE Asúa, Códigos, Vol. I, p. 111. 
uno de los Códigos modernos más perfectos, de técnica irreprochable y mejor escritos"64.

26. A aplicação das sanções assenta-se nos seguintes artigos da lei penal do Uruguai :' 50 a 58 e 86 a 90 . 0 art. 86 é a sede da individualização judicial da pena, com a seguinte disposição: "El Juez determinará, en la sentencia, la pena que en su concepto corresponda, dentro del máximo y el mínimo señalado por la ley para cada delito, teniendo en cuenta la mayor o menor peligrosidad del culpable, sus antecedentes personales, la calidad y el número - sobre todo la calidad -, de las circunstancias agravantes $y$ atenuantes que concurran en el hecho.

Tratándose de delitos sancionados con pena de prisión, cuando concurran atenuantes excepcionales, el Juez tendrá la potestad de bajar a la de multa que aplicará conforme al inciso precedente".

Os arts. 87,88 e 89 cuidam da individualização da pena, respectivamente, nos casos de tentativa, coautoria e participação de cúmplices, complementando, assim, o dispositivo individualizador.

Do exame do art. 86, verifica-se que o juiz é autorizado a aplicar a pena que melhor convier, deixando a qualidade da sanção a seu critério, e advertindo-o, tão-só, em relação à quantidade. Destaca, logo após, como de especial relevância para a consideração do julgador, o índice de maior ou menor periculosidade do culpado. Por isso, o delinqüente deve ser encarado, não só através dos requisitos de sua personalidade, como também em relação ao que constitui a relação de fato que no delito se retrata. Sua capacidade de delinqüir e a possibilidade de que venha a reincidir na prática de atos anti-sociais, devem ser aferidas através do exame circunstanciado dos antecedentes e da constituição psicofísica do réu. A qualidade e a quantidade das circunstâncias, que possam atenuar ou agravar a sanção,

64. Jorge Eduardo CoLl, El Código Umuguayo, em "Criminalia", 1936 , p. 6. 
completam, no final do dispositivo, o quadro oferecido ao juiz para a formação de sua livre conviç̧ão e a conseqüente dosagem da pena a ser aplicada em cada caso.

Quanto à pena de multa, além de ser facultado ao juiz cominá-la em substituição à de prisão, quando ocorram atenuantes excepcionais, conforme determina o final do art. 86, deverá graduá-la de acôrdo com "los bienes y recursos del delincuente", na conformidade com o art. 83 .

27. A individualização da pena é, no consenso geral, uma das grandes conquistas do Direito Penal uruguaio. Na Exposição de motivos, Goyena justifica sua adoção, através das seguintes palavras: "La grand latitud que se otorga a los magistrados, en la aplicación de las medidas de defensa, según las características del delincuente, corresponden a la individualización judicial.

Esa latitud es el resultado de dos providencias: la sensible deveryencia entre el máximum y el mínimum de la pena establecida para cada delito, y las faculdades que se le discieruen al Juez para pasar libremente de un extremo a otro, según el concepto que se forme de la peligrosidad del delincuente".

Rafael Fontecilla R. analisando o Código uruguaio, entre outras, faz estas considerações: "Debemos destacar todavia una nueva bondad, el arbitrio judicial. Consecuente con la tesis individualizadora, se proclama un amplio, como discreto arbitrio para los jueces. Es absurdo pretender la individualización judicial del tratamiento, si no otorgamos al juzgador una mayor elasticidad en la aplicación de las sanciones"65.

De nossa parte, desconhecemos referências aos possíveis resultados negativos que a aplicação do art. 86 venha obtendo. Nas pesquisas que fizemos em tôrno dêsse dispositivo individualizador, também não encontramos qualquer

65. Rafael Fontecilla, El Proyecto de Código Penal para la República del Uruguay, em "Anales de la Universidad de Chile", Santiago, 1934 , p. 25. 
notícia relativa à oposição de magistrados uruguaios às providências que êle determina.

28. Ao término dêste capítulo, devemos, entretanto, ressaltar que, mesmo nos códigos em que a individualização da pena não mereceu expressa acolhida, observa-se a concessão de apreciável arbítrio judicial na cominação das penas pecuniárias. Alguns dêles, embora fiéis a uma rígida dosimetria em relação às demais penas, abrem larga margem de liberdade ao julgador na aplicação da multa, em dispositivos, muitas vêzes, bem mais amplos que os observados nos códigos cuja orientação já estudamos.

Entre êstes, devemos mencionar o do Paraguai, que, em seu artigo 84, estipula: "Para graduar la multa el Juez tendrá en cuenta, no solo la gravedad de la infracción y las circunstancias atenuantes $\mathrm{y}$ agravantes, sino también la condición social y facultades del culpable". Os estatutos penais de Salvador e Honduras, por igual, determinam, respectivamente, nos arts. 59 e 71 que, na aplicação da pena de multa, com seu "prudente arbitrio", o juiz deverá atender às "circunstancias atenuantes y agravantes, $\mathrm{y}$ principalmente el caudal o facultades del culpable".

IV.

\section{A individualização legal da pena no Direito Penal Comparado latino-americano.}

29. Todos os códigos penais, como é óbvio, contemplam a individualização legislativa da pena, pois, conforme observa o Prof. Frederico Marques, é ela que "domina e dirige as demais, porque é a lei que traça as normas de conduta do juiz e dos órgãos da execução penal, na aplicação das sanções"66. Ela está na base de todo o sistema repressivo, antecedendo lògicamente às individualizações

66. Frederico Marques, ob. cit., p. 236. 
judicial e administrativa, traçando-lhes as diretrizes e estabelecendo seus contornos e limitaçốes.

Nas codificações penais latino-americanas estudadas no capítulo anterior, a individualização legal é feita parcimoniosamente, fixando apenas critérios gerais e deixando aos juízes certo arbítrio para, dentro dos limites e condições preestabelecịdas pela lei, fazer a aplicação das sanções penais.

Todavia, os estatutos penais dos demais países da América Latina, notadamente os que não receberam qualquer influência do moderno Direito Penal, mantendo-se fiéis aos postulados da Escola Clássica e à orientação que lhes deu o antigo Direito espanhol, acolhem um rígido sistema de individualização legal. Neles as penas são prèviamente dosadas, sem deixar margem ao magistrado para aplicá-las na conformidade de seu livre convencimento. São os velhos códigos, explica Asúa, "que assumen el criterio de desconfianza hacia el juzgador y dan normas minuciosas para aplicar las penas haciendo una espécie de individualización legal"67. A estas leis juntam-se, entretanto, algumas de elaboração recente, mas com excessivo apêgo à tradição e a princípios já superados, inclusive o mais nôvo de tôda a América, o Código Penal de Costa Rica, promulgado em 1941.

30. Estas codificações podem, ainda, ser agrupadas em dois tipos: o primeiro, que reúne as leis penais contendo regras minuciosíssimas na cominação das sanções, acompanhadas, em algumas delas, de "tabelas" indicativas da qualidade e da quantidade da pena a ser aplicada em cada caso; e o segundo, constituído pelos códigos que, embora neguem o arbítrio judicial, não se apegam, todavia, a uma individualização legal absoluta.

No primeiro caso, encontra-se o mais antigo Código Penal do continente, o velho estatuto da Bolívia, promul-

67 LUis Jiménez de Asúa, Códigos, Vol. I, p. 384. 
gado em 1834. Em seus arts. 27 a 34,37 a 46 e 89 a 99 estabelece um mecanismo rigoroso para aplicação das penas, sòmente superado pelo do Chile. $O$ art. 27 estatúi que "a ningún delito ni culpa se impondrá nunca otra pena, que la que le señala alguna ley promulgada ocho días al menos antes de su perpetración". O artigo seguinte especifica nove tipos de penas corporais e treze modalidades de não-corporais, enquanto que, nos que se lhe seguem, são fixados os graus máximo, sub-máximo, médio, sub-médio e mínimo das penas. bem como a maneira com que o julgador deverá apreciar cada delito, podendo o total da sanção cominada reduzir-se a meses, a dias, e até a horas. Para as reincidências a tabela anexa ao art. 92 é rica em, detalhes, discriminando, em diversas colunas, a qualidade e a quantidade da sanção adequada, até à terceira reiteração no crime pelo mesmo sujeito.

O Código Penal do Chile é, entre todos, o mais dosimétrico. Pelo seu art. 56, "las penas divisibles constan de tres grados". as quais se aplicam de acôrdo com "la siguiente tabla demonstrativa", que prevê nada menos que dezessete tipos de penas e os tempos previstos para os diversos graus. Por fim, o art. 61 contém nova e mais detalhada tabela, em que são estatuidas as cominações para reincidências, os delitos tentados, os consumados e a participação de cúmplices.

O mesmo se diga dos Códigos Penais da Nicarágua, El Salvador, Guatemala e Honduras. Dêstes, merece especial destaque o art. 67 do estatuto guatemálteco, pois determina que "Los Jueces no podrán aumentar, disminuir, agravar ni atenuar las penas, ni substituilas con otras o añadirles alguna circunstancia sino en los términos y casos que las leys prescriben".

No segundo grupo, isto é, naqueles códigos em que o rigor não chega a ponto de exigir tabelas para a fixação das penas, segundo as diversas hipóteses, situam-se os demais países latino-americanos. 
Nessas leis penais são os seguintes os artigos que cuidam da aplicação das penas, os quais deixamos de comentar por julgarmos desnecessário para o âmbito dêste trabalho: Paraguai, arts. 63 a 65 e 86 a 105; Panamá, arts. 30 a 32 e 60 a 81 ; Venezuela, arts. 37 a $59,78,79,82$ e 84 a 101; Equador, arts. 76 a 85; Costa Rica, arts. 34, 40, 43 a 45, 49 a 52 e 81 a 87; Haiti, art. 382; e República Dominicana, arts. 462 e 463.

31. Observa-se, entretanto, que nos países onde a aplicação das penas obedece a rigidas determinações legais, desenvolvem-se amplos movimentos doutrinários e mesmo jurisprudenciais no sentido da aceitação do arbítrio judicial.

Na Bolívia, várias tentativas já foram feitas, porém sem lograr êxito. O Projeto Salmón de 1935 transcrevera o art. 41 do Código argentino que, como vimos, concede ampla liberdade ao juiz na cominação das penas; enquanto que o Projeto Ossío de 1939, de fundo positivista, seguiu idêntica orientação. Por fim, no estudo de reforma de 1941, feito por Manoel Lópes Rey y Arroyo, esclarece Manuel Duran, procurava-se "suprimir la restricción que ha sufrido el arbitrio judicial", estabelecendo, em seu art. 9, que "la ley se tendrá siempre en cuenta la personalidad del delincuente"68.

Para o Chile, o Projeto Erazo-Fontecilla de 1929, já previa o arbítrio judicial, enquanto que o de 1938, elaborado por um grupo de juristas, pouco acrescentava ao Código vigente.

O Projeto Chiossone de 1938 para a Venezuela, de filiação político-criminal, acolhera amplamente as medidas de segurança, aceitando, com razoável largueza, a individualização judicial da pena.

Observam-se em outros países da América Latina idênticos movimentos. As cátedras universitárias, sensiveis a

68. Manuel Duran, La Reforma Penal em Bolivia, Sucre, 1946, p. 6 . 
êsses reclamos, no mais das vêzes assumem posição de vanguarda. As casas legislativas, entretanto, se têm portado com indiferença quase total diante das reformas pretendidas, conseqüências que são da indiscutível evolução da ciência penal no mundo latino-americano.

$\mathrm{Na}$ revista mexicana "Criminalia", que dispõe de grande penetração em todos os países de origem espanhola, encontramos, em seus vários volumes, um registro muito sincero dessas aspirações, através de trabalhos de ilustres juristas e professôres de diversas nacionalidades.

V.

A individualização administrativa da pena no Direito Penal Comparado latino-americano.

32. Sob o aspecto da individualização administrativa da pena, as nações latino-americanas têm também muito que oferecer aos que se proponham a inquiri-las nesse moderno setor da ciência penal.

Ao ensejo dêsses estudos, surge, desde logo, o problema da sentença indeterminada. Foi em Pôrto Rico, que culturalmente faz parte do mundo latino, embora politicamente esteja ligado à União Norte-Americana, que êsse instituto jurídico conseguiu impor-se decisivamente no Direito positivo.

Pela Lei n. ${ }^{\circ}$ 295, de 10 de abril de 1946, a sentença indeterminada foi oficialmente instituida naquele país. Em seu subtítulo, diz a referida lei: "Proveyendo para el establecimiento de la sentença indeterminada y para su funcionamento, en relación con el sistema de liberdad bajo palabra, y para otros fins", enquanto que seu art. $1 .^{\circ}$ estipula: "Por la presente ley se establece la sentencia indeterminada en Puerto Rico, disponiendose, que cuando los tribunales condenaren a un reo a cumplir sentencia por delito grave, que no apareje pena de reclusión perpetua, dictarán una sentencia indeterminada...". 
o Peru, por seu turno, realiza a individualização administrativa através das "penas indeterminadas". Aboliu as sanções fixas, que foram substituídas pelas absoluta ou relativamente indeterminadas. A pena de internamento (art. 11), por exemplo, com um mínimo fixado em 25 anos, é absolutamente indeterminada, enquanto que a de relegação (art. 13), entre outras, pode ser tanto indeterminada, como de prazo fixo.

Fora dêsses casos, a sentença indeterminada não logrou qualquer êxito no Direito Penal legislado latino-americano. Entretanto, antecedentes houve em outros códigos, que, embora não constituam pròpriamente a sentença indeterminada, podem realizar parte de seus objetivos. E o que se depreende, "verbi gratia", da leitura do art. 100 do Código Penal boliviano: "Por medio del arrependimiento y de la enmienda, pueden los reos rematados sin distinción de classe y fuero conseguir la rebaja de las penas a que han sido condenados...". É um remoto antecedente do moderno instituto do livramento condicional.

No Brasil, o problema da sentença indeterminada tem movimentado congressos e reunido apreciável número de defensores. Os primeiros esforços datam de 1900, com Bezerra Morais, no Congresso Penitenciário de Bruxelas. No Congresso Jurídico de 1908, foi proposta e recusada a tese: "Pode ser adotado, sem prejuízo das garantias devidas à liberdade individual, o sistema das sentenças indeterminadas?" Mereceu, entretanto, aprovação a indeterminação relativa.

Embora não acolhida pelo Código Penal de 1940, a indeterminação das penas ou das sentenças tem, entre nós, conseguido alguns êxitos. O art. $63, \S 10^{\circ}$, da "Consolidação", cuidando da internação de índios em colônias correcionais, deixa ao inspetor a fixação de sua duração; o Código de Menores, em seus arts. 80, 81 e 82 ; o Decreto $n .^{\circ} 24.645$, que regula a proteção aos animais, no $\S 1 .^{\circ}$, do art. $2 .^{\circ}$; e o Código Florestal, no seu art. 71, estabelecem duração indeterminada para as sanções que cominam. 
33. Pedro Vergara, entre outros autores, entende que o art. 32 do Código de 1940 é a sede da individualização administrativa no Direito repressivo brasileiro. Julgamos, entretanto, que o referido dispositivo apenas estabelece as linhas gerais para o regulamento de nossas organizações penitenciárias, sem resolver, por si só, o problema da individualização da pena em sua fase executória.

$O$ questionado artigo contém, tão-sòmente, uma orientação geral para ser observada na fixação dos regulamentos de nossas prisões. deixando que suas normas sejam melhor particularizadas em um futuro Código Penitenciário, cuja promulgação já não mais pode ser protelada. Aliás, dentro do plano de reforma geral das codificações brasileiras, elaborado pelo Govêrno Federal, o Prof. Roberto Lyra encarregou-se da feitura de um anteprojeto de "Código das Execuções Criminais" que, segundo se divulga, conterá inúmeras inovações no que se refere à individualização administrativa da pena.

Todavia, como antecipação dêsse desejado estudo de disciplina penitenciária, a Lei $n .^{\circ} 3.274$, de 2 de outubro de 1957, procurou, em atenção ao que exige o art. $5 .^{\circ}, \mathrm{n}^{\circ} \mathrm{XV}$, letra " $b$ ", da Constituição Federal, estabelecer as normas gerais do regime penitenciário brasileiro, através de dispositivos que vão desde a exigência da classificação dos sentenciados para efeito do cumprimento das penas, até a especificação dos estabelecimentos penais padronizados e órgãos técnicos necessários à execução da individualização da pena em sua fase executória.

Releva notar, ainda, que a mencionada lei estabelece, antes de mais nada, em seu art. $1 .^{\circ},{ }^{\circ}{ }^{\circ} \mathrm{I}$, como principio básico, "a individualização das penas, de modo que a cada sentenciado, conhecida a sua personalidade, corresponda tratamento penitenciário adequado".

34. Mesmo sem acolher a sentença indeterminada, os Códigos Penais latino-americanos, na sua maioria, vêm fazendo a individualização administrativa da pena, através 
de certas medidas complementares. São estas diversos institutos jurídicos intimamente ligados ao assunto, que assumem, às vêzes, características peculiares a cada país. Entre elas, podem ser citados, pela largueza com que são exercitados, o "sursis", o livramento condicional e o amplo campo de verificação das medidas de segurança, enquanto que o perdão judicial mereceu acolhida mais restrita.

NÉlson Hungria, com algum exagêro, chegou mesmo a dizer que, "depois que o livramento condicional e as medidas de segurança tiveram ingresso no sistema do Direito Penal positivo, falar de pena indeterminada é qualquer coisa como pleitear 'o retôrno das espingardas de carregar pela bôca" $" 69$.

35. O instituto da suspensão condicional da pena, que, com a finalidade de evitar os inconvenientes das penas de curta duração, permite seja, sob determinadas condições, sobrestado a cumprimento da sanção cominada pelo juiz, foi acolhido por nada menos que onze legislações penais latino-americanas (Argentina, arts. 26 a 28; Panamá, art. 29; Peru, arts. 53 a 57; México, art. 90; Uruguai, art. 126; Cuba, art. 97; Chile, arts. 80 a 84; Guatemala, art. 51; Equador, arts. 86 a 90 ; Brasil, arts. 57 a 59 ; e Costa Rica, arts. 90 a 96).

Todos êsses códigos se filiam, nesse particular, ao chamado "sistema continental europeu", que, de acôrdo com o ensinamento preciso de Roberto LyRA, consiste "na suspensão da execução da pena decretada pelo juiz. Este profere a condenação e, ao mesmo tempo, ordena a suspensão da execução da pena, segundo certos pressupostos. Decorrido sem condenação o período fixado na sentença, cessa o direito do Estado de executar a pena"70.

Exigem êsses estatutos penais para a concessão do benefício que o réu seja primário, salvo o de Cuba, que não faz menção a êsse requisito, mas estabelece como obriga-

69. Néllson Hungria, Comentários ao Código Penal, Vol. IV, 1956, p. 107.

70. ROBerto LYRA, ob. cit., p. 397 . 
tório que "concurran dos o más circunstancias atenuantes personales o de menor peligrosidad" (art. 97). O limite da pena para a qual a suspensão pode ser concedida varia muito entre êsses países. Assim é que o Código de Costa Rica fixa em três anos o máximo da pena cominada (art. 90); os da Argentina (art. 26), do México (art. 90), do Uruguai (art. 126) e do Brasil (art. 57), em dois anos; os de Cuba (art. 97) e Guatemala (art. 51) não permitem o benefício para as condenações superiores a um ano; e, por fim, três outros códigos estabelecem prazo ainda menor para êsse limite, que é de seis meses para os do Peru (art. 53) e Equador (art. 86), de quatro meses para o do Panamá (art. 29).

Por outro lado, excetuando os Códigos do Brasil, Colômbia, Guatemala e México, que não estendem a suspensão à pena pecuniária, todos os demais que acolhem o instituto incluem a multa entre as penas sujeitas a êsse favorecimento (Argentina, art. 26; Panamá, art. 29; Peru, art. 53; Uruguai, art. 126; Cuba, art. 97; Equador, art. 86; e Costa Rica, art. 90).

36. O livramento condicional, ou seja, "a liberdade provisória concedida, sob certas condições, ao condenado que não revele periculosidade, depois de cumprida uma parte da pena que lhe foi imposta", segundo a conceituação de Frederico Marques ${ }^{71}$, aparece, pela primeira vez, na América Latina, no velho Código Penal da Bolívia.

Efetivamente, diz o art. 100 dêsse estatuto: "Por medio del arrepentimiento y de la enmienda, pueden los reos rematados sin distinción de clase y fuero conseguir la rebaja de las penas a que han sido condenados, después de haber sufrido al menos una tercera parte de ellas..."

Segundo o mesmo critério, adotou-se o livramento condicional em bom número de códigos latino-americanos, mesmo naqueles em que o sistema progressivo ou irlandês,

71. Frenerico MARQUes, ob. cit., p. 285. 
do qual o instituto é elemento integrante não mereceu acolhida, fixando-se estas condições: "haber cumplido una parte de la pena privativa de liberdad y haber observado buena conducta".

0 "quantum" da pena que devem cumprir os réus para a concessão da liberdade condicional varia em relação a essas legislações. Uns códigos fixam essa porção em três quartas partes da sanção cominada (Salvador, art. 19; Panamá, art. 20; Venezuela, arts. 52 a 56; e Cuba, arts. 98 e 99); outros, em dois tercos (Argentina, arts. 13 a 17; Peru, arts. 58 a 64; México, arts. 84 a 87; e Costa Rica, arts. 97 a 101). O Código do Paraguai, que acolheu o sistema progressivo, prevê o livramento condicional no quarto período, desde que a conduta do recluso tenha sido irrepreensível no estágio anterior (art. 68). A lei penal do Uruguai estabelece os prazos de cumprimento de acôrdo com o tipo de sanção: se é de natureza "penitenciária", o réu deverá ter cumprido a metade da pena que lhe foi imposta; e se se trata de pena de prisão ou de multa, a concessão poderá ser feita "sea cual fuere el tiempo de detención sufrida" (art. 131). $\mathrm{O}$ Código colombiano segue-lhe de perto. Imposta a pena de "presídio", o candidato ao benefício deverá ter cumprido três quartas partes da condenação, mas em se tratando da pena de prisão ou arresto não inferior a dois anos, o cumprimento limita-se às duas terças partes (arts. 85 a 90). A Guatemala também faz a distinção: três quartas partes, se a pena é de prisão, e o que falta por cumprir-se na pena de arresto, desde que a condenação tenha sido superior a nove meses (arts. 49 a 50). Para o Código Penal do Equador o prazo de cumprimento é fixado em três quartas partes para a pena de reclusão e em duas terças partes, em relação à pena de prisão correcional (arts. 91 a 94).

O Código Penal do Brasil, ao contrário da maioria dos estatutos repressivos latino-americanos, não exclui os reincidentes do benefício da liberdade condicional. 0 critério para a fixação dos prazos fundamenta-se, por isso, no problema da reincidência: se o delinqüente é primário, 
deverá cumprir tão-sòmente a metade da pena; mas, se já sofreu condenação anterior, exige-se que o réu tenha consumido mais das três quartas partes da sanção que lhe foi imposta (arts. 60 a 66 ).

37. O perdão judicial, também causa extintiva da punibilidade. e que alguns autores entendem deva ser incluído, com mais rigor. entre as medidas que propiciam a individualização judicial da pena, é também providência que visa evitar a execução das penas de curta duração.

Teve restrita aceitação na codificação penal latinoamericana, pois aparece, tão-sòmente, nos estatutos dà Colômbia, Uruguai e Brasil.

No Código colombiano o instituto é previsto para os casos de "falsas imputaciones hechas ante las autoridades" (art. 190); de "falso testimônio" (art. 195); de abôrto "honoris causa" (art. 398); e de "homicidio piadoso" (art. 364). Para a lei penal do Uruguai essa providência de caráter jurisdicional pode ter lugar nos seguintes delitos: "homicidios y lesiones por causa de adultério" (art. 36); "homicidio piadoso" (art. 37); "de reconocimiento como hijo legítimo de una persona que careciere de estado civil, cuando los móviles fueren la piedad, el honor o el afecto" (art. 39); de "injuria o difamación" (art. 40); de infrações cometidas por menor de 18 anos, se fôr boa "su conducta anterior y sus guardadores ofrecen garantías de suficiente asistencia moral" (art. 45).

No Código Penal do Brasil, embora o instituto não figure expressamente na parte especial, aparece, todavia, em diversas hipóteses: "Crime de injúria" (art. 140, § 1. ${ }^{\circ}$ ); "Outras fraudes" (art. 176, § único); "Receptação culposa" (art. 180, § 3..$^{\circ}$ ) ; "Adultério" (art. 240, $\S 4 .^{\circ}$ ); e "Subtração de incapazes" (art. 249, $\S 2^{\circ}$ ). Por outro lado, a Lei das Contravenções Penais prevê o perdão judicial nos casos de "Érro de direito escusável" (art. 8. ${ }^{\circ}$ ) e de "Associação secreta" (art. $39, \S 2 .^{\circ}$ ), o mesmo acontecendo com a Lei de 
Falências (art. 186, $\S$ único) e a Lei de Imprensa (art. 12, $\S 3 .{ }^{\circ}$ ).

38. As medidas de segurança, com o caráter de sanção penal predominantemente preventiva, e que objetivam evitar a reincidência para os delinqüentes que se revelaram dotados de periculosidade, desempenham, por igual, papel da maior relevância na chamada individualização administrativa da pena.

Tiveram ampla aceitação nos códigos penais da região centro-sul das Américas de feitio moderno, embora não figurem no Código Penal da Argentina, que se coloca entre aquêles.

São medidas de inspiração político-criminal que, todavia, projetando-se para além de seus limites originários, vieram alcançar algumas legislações de filiação diversa, assumindo, por vêzes, coloridos próprios em alguns países. Com seu caráter indeterminado, na prática, se traduzem em providências as mais diversas, as quais, num esbôço geral, assim se discriminam, nas diferentes legislações latinoamericanas :

a) a relegação, que se apresenta não raro com um caráter misto, situando-se entre as penas pròpriamente ditas e as autênticas medidas de segurança, e que em alguns códigos é imposta por tempo indeterminado (Argentina, arts. 51 e 52; Panamá, arts. 13 e 19; México, art. 24, n. ${ }^{\circ}$, e arts. 27 e 66, após o Decreto de 31 de dezembro de 1943;

b) internamento em hospital, manicômio judiciário ou colônia agrícola especial para doentes mentais ou indivíduos de alta periculosidade (Peru, arts. 89 e 92; México, art. 68; Colômbia, arts. 61 a 64; Uruguai, art. 97; Cuba, arts. 586 e 588; Brasil, art. 91; e Costa Rica, arts. 111 a 113);

c) internamento em colônias agrícolas ou casas de custódia e tratamento para os grandes criminosos (Uruguai, arts. 92 a 99; Cuba, art. 588; e Brasil, art. 93); 
d) colocação em casa de tratamento para delinqüente ébrio habitual (Peru, art. 41; Cuba, art. 588; e Brasil, art. 92);

e) liberdade vigiada para enfermos mentais e intoxicados (Colômbia, arts. 61 e 67);

f) proibição de exercer determinadas profissões (Colômbia, art. 75) ;

g) reclusão em escola ou estabelecimento especial para surdo-mudo, pelo tempo necessário (México, art. 67; e Uruguai, arts. 92, 94 e 95). O Código venezuelano só se refere ao surdo-mundo menor;

h) trabalho em obras públicas ou emprêsas públicas para os alcoólatras e toxicômanos (Colômbia, arts, 61 e 65);

i) proibição de freqüentar determinados lugares públicos para alcoólatras e toxicômanos (Colômbia, arts. 61, 65 e 76; Cuba, art. 586; e Costa Rica, art. 115);

j) caução de boa conduta (Peru, arts. 38 a 40; Uruguai, arts. 100 a 102; e Cuba, arts. 585, 589 a 591); e

k) expulsão de estrangeiro (Cuba, art. 585; Brasil, art. 101; e Costa Rica, art. 118).

Todavia, mesmo os códigos do tipo clássico, que desconhecem as autênticas medidas de segurança, reservam algumas providências do tipo não penal para serem aplicadas aos inimputáveis. É o que ocorre, por exemplo, com os "enajenados, que serán recluidos en un establecimiento destinado a enfermos de aquella clase" (Chile, art. 10, 1. Nicarágua, art. 21; Salvador, art. 8; Honduras, art. 7 e Paraguai, art. 18). O mesmo dispositivo também se insere em algumas legislações que, embora modernas, repudiam as medidas de caráter não penal (Argentina, art. 34; $\mathrm{Pa}$ namá, art. 44; Venezuela, art. 62; Guatemala, art. 21; e Equador, art. 34). 
VI.

\section{Conclusões.}

39. A individualização da pena, instituto que se impôs no elenco das legislações penais modernas, teve satisfatória acolhida por parte das codificações latino-americanas. Aceita pela maioria dos países que, neste século, alteraram suas leis repressivas, continua, no entanto, a agitar a doutrina e a jurisprudência daqueles que, fiéis à orientação dos penalistas clássicos, ainda se apegam a uma rígida dosimetria penal. Os diversos projetos de reforma dessas legislações dados à publicidade timbram em inscrever como fundamental em seu texto o principio da adequação da pena tanto ao delito como à pessoa do delinqüente.

Coube à comparação, inegàvelmente, papel da maior relevância na formulação dos preceitos que possibilitaram essa aceitação, enquanto que, o Direito Penal brasileiro, històricamente vinculado às origens do Direito latinoamericano, ocupa posição de vanguarda no fornecimento de subsídios para a elaboração dos mais recentes textos penais, no setor da individualização da pena.

Todavia, nos diferentes países onde o instituto foi inscrito no Direito legislado, os resultados que se vêm obtendo com a aplicação dos dispositivos individualizadores não são de encorajar. Os comentadores são quase unânimes em afirmar que, por êste ou aquêle motivo, o arbítrio judicial é letra morta no texto das leis.

As razões dessa inaplicabilidade são inúmeras e complexas. Delas destacamos, a seguir, as que se nos afiguram de maior relevância, ao mesmo tempo que arrolamos algumas providências que nos parecem recomendáveis, numa tentativa de solução do problema:

1. ${ }^{\text {) }}$ A tradição do Direito latino-americano, com suas vinculações ao Direito espanhol, fiel à dosimetria penal, segundo as diretrizes da Escola Clássica. Para esta a 
preocupação com a pessoa do delinqüente é meramente acidental, pôsto que ao delito, como entidade jurídica, devem carrear tôdas as atenções do julgador. Nestas condições, as sanções penais assumem caráter mais intimidativo do que educativo, fazendo a individualização, tão-sòmente, em relação ao dano produzido.

Esta orientação, arraigada em respeitável parcela de doutrinadores e magistrados, tem impedido que, mesmo nos países em que o arbítrio judicial logrou boa acolhida, na prática, se tenha conseguido os resultados almejados pelo Iegislador. $O$ que se passou no Peru, logo após a promulgação do Código de 1924, diz bem dêste estado de coisas. Opondo-se à adoção das medidas de segurança e à derrogação das antigas normas para a fixação das penas, a magistratura daquele país, tão logo foi pôsto em vigor a nova lei, cuidou de constituir uma comissão encarregada de reformá-la.

No Brasil, observa o Prof. Basileu Garaia, "por amor à tradição, por hábitos conservadores enraigados, o delinqüente é processado exatamente pela maneira que se empregaria se tivéssemos um Código Penal do tipo rigorosamente clássico e a pena devesse inflingir-se segundo a dosimetria ditada tão-só pelas circunstâncias mais aparentes"72.

Urge, pois, que se desenvolvam campanhas de esclarecimentos para que os códigos, embora embuídos de preceitos modernos, deixem de sofrer a influência de uma parcela retrógrada de juristas e juízes, que tolhem sua total aplicabilidade;

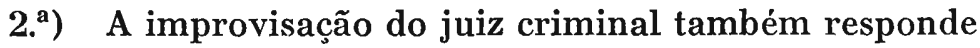
pela falência da individualização da pena.

O problema da especialização da magistratura é dos mais importantes no moderno Direito Penal, em face da soma de aspectos que suscita. Daí ter afirmado com pro-

72. Basileu Garcia, Reforma da Pena de Multa, na "Revista dos Tribunais", Vol. 306, p. 23. 
priedade Mariano Ruiz FuñEs: "Hacer un Código es tarefa relativamente fácil. Hacer un juez es labor ardua"73.

Reconhecemos que o problema não é de fácil solução, pois envolve ângulos bem delicados, que nem sempre podem ser enfrentados sem algum constrangimento.

Muitos legisladores não escondem sua preocupação em face do assunto, procurando, em decorrência, restringir o arbítrio judicial. Alcântara Machado perfilou-se entre êles. No seu "Projeto de Código Criminal", ao enfrentar a questão, colocou na justificativa de seu trabalho estas palavras: "Estará a nossa magistratura preparada para uma tarefa dessa magnitude? Ninguém o afirmará, sem afrontar a evidência. Daí a timidez, ou, melhor, a prudência do ante-projeto".

O problema da especialização do magistrado criminal não é nôvo. Já no Congresso da União Internacional de Direito Penal de 1815, os debates sôbre a matéria adquiriram grande colorido, deles resultando, de prático, o "Curso" de VoN Liszr para a formação de juízes especialistas. No Congresso Penitenciário Internacional de Londres, em 1925, decidia-se que "o juiz criminal deve consagrar-se exclusivamente a êste ramo da magistratura e ter nêle todos os meios e possibilidades de progresso", enquanto que no III Congresso Internacional de Direito Penal de 1923, realizado em Palermo, e por Carnevale denominado "O Congresso do Juiz", se recomendava ser "necessário orientar a organização judicial em cada país para uma maior especialização do juiz criminal".

Por seu turno, o I. $^{\circ}$ Congresso Latino-Americano de Crimonologia de Buenos Aires, em 1938, ao considerar as diversas comunicações sôbre o tema "La preparación cientifica del Juez del Crimen", resolvia: "Recomendar la conveniencia de organizar, sobre la base de la preparación teórica y practica antedicha, la carrera judicial o adminis-

73. Marlano RuIz Fuñes, El Juez Penal, em "Criminalia", 19411942, p. 170 . 
trativa de las personas llamadas a participar en la justicia del crimen" e "Recomendar la creación de cursos postuniversitarios de especialización destinados a la preparación teórica y practica de las personas llamadas a intervenir en el ejercicio de la justicia en lo criminal".

Como se vê, na América Latina, o problema vem sendo enfrentado com alguma determinação. Daí ter resultado a criação de diversos cursos ou institutos especializados em diversas de suas universidades, ou mesmo autônomos, objetivando a conveniente preparação técnico-científica do juiz criminal. Entre êstes, podem ser citados, segundo informa CÉSar Salgado", o "Curso Biopsico-criminal" da Universidade de Areripa, no Peru, e o "Instituto Técnico-Forense", fundado por Abel Zamona, no Uruguai. Na Colômbia, logo após a promulgação do código vigente, foram instituídos cursos de especialização jurídico-criminal, exigindo-se como indispensável para o ingresso na magistratura a prova de haver concluido um dêsses cursos.

No Brasil espera-se, por igual, apreciável contribuição do "Instituto Latino-Americano de Criminologia", recentemente instalado em São Paulo, sob a égide da onv, enquanto que o "Instituto de Criminologia" da Universidade da Guanabara, já vem colhendo alguns frutos nesse setor de suas atividades.

A exigência da especialização do juiz do crime, em alguns países alçou aos textos legais, valendo citar, a título de exemplo, o que dispõe o art. 636, do "Código de Procedimientos Penales" do México, para o Distrito e Territórios Federais, no qual o candidato à judicatura "deberá comprobar, además, a juicio del Tribunal Superior de Justicia, que ha estudiado e practicado especialmente Derecho Penal. La especialización se comprobará por certificados universitários y la practica por medio de documentos fehacientes".

A especialização da magistratura criminal se nos afigura, portanto, como um dos fatôres capazes de recolocar o

74. CÉSAR SALGADo, Especialização da Magistratura Criminal, em "Archivo Judiciario", Vol. 67, p. 101. 
instituto da individualização da pena na fundamental posição que lhe reservaram os legisladores, dentro da sistemática dos códigos modernos;

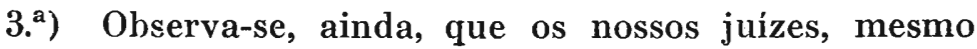
aquêles que dispõem de atualizada formação técnicocientífica, não costumam utilizar os poderes mais ou menos amplos que lhes confere a lei, na cominação das sanções. Ou por timidez, ou, conforme acentua o Prof. Basileu Garcia, "pelo sentimento de benevolência, raro se valem da possibilidade legal de agravar a situação do acusado dentro de uma certa margem de escolha. Optam pelas soluções mais suaves" $" 75$.

Mesmo em relação à pena pecuniária, para a qual algumas leis especiais estipulam para o limite máximo importâncias muito superiores às fixadas pelo Código de 1940 , o mesmo se verifica.

O problema da não utilização pelos magistrados dos dispositivos individualizadores das leis penais, liga-se ìqueles focalizados acima, completando, dessa forma, no quadro formador da inaplicabilidade do arbítrio judicial, a parcela de culpa que deve ser atribuída aos julgadores;

4.. $)$ No que respeita aos fatôres não ligados diretamente à magistratura, ressalta, desde logo, como causa para o agravamento do problema, a carência que se observa de jaboratórios e institutos especializados e eficientes dos quais se possam valer os juizes na obtenção de dados para o estudo da personalidade do delinqüente.

O magistrado, não raro, só dispõe de notícias sôbre os antecedentes judiciais e policiais do acusado. Os elementos biopsíquicos que atuam no comportamento daquele que deve prestar contas à justiça, de fundamental importância para uma perfeita adequação da pena tanto ao crime como ao seu autor, fogem, invariàvelmente, às páginas do processo.

75. Basileu Garcia, art. cit., p. 23. 
É verdade que os países latino-americanos dispõem de alguns órgãos que podem perfeitamente realizar essas tarefas, como o nosso "Instituto de Biotipologia Criminal", que tem merecido fartos elogios de penalistas de elevado gabarito, como Rulz Fuñes, Lópes Rey y Arroyo, Beleza dos SANTos e outros. Mas o ideal seria a descentralização dêsses serviços, com o desacúmulo de atribuições para um melhor atendimento, principalmente às comarcas do interior.

As chamadas "clínicas criminais", tão difundidas na Europa, poderiam, dentro de nossas condições próprias, dar satisfatória solução ao problema;

5. $\left.{ }^{a}\right)$ A falta de melhor entrosamento entre as leis penais e as leis do processo penal figura também entre as razões do descrédito do instituto da individualização da pena. Para alguns é a causa principal.

O fenômeno é crônico e abrange todo o Direito latinoamericano. Freqüentemente deparamos com críticas veementes aos "Códigos de Procedimientos Penales" e ao divórcio que se estabeleceu entre êles e os respectivos códigos penais. No Brasil, é o Prof. Basileu Garcia quem o afirma, "a individualização da pena, erigida pelo Código à categoria de princípio fundamental, não tem tido a desejável realização, porque o processo penal, mal dileneado, não torna acessíveis ao juiz os esclarecimentos imprescindiveis acêrca da personalidade do réu, suas condições individuais, para um razoável ajustamento da providência de defesa social ao autor do crime" $"$.

O fato de o Código de Processo Penal ter acolhido o princípio da "livre convicção" do órgão judicante no manejo das provas (art. 157) não the deu, por si só, condições suficientes para determinar uma justa e acertada orientação na aplicação das sanções. Se, na prática, êsse dispositivo algumas vêzes tem sido utilizado com acêrto pelos nossos julgadores, os demais artigos de nossa lei penal adjetiva

76. Basileu Garcia, art. cit., p. 23. 
neutralizam-lhe os efeitos, por falta da necessária complementação.

É inadiável a mudança dessa anacrônica lei de processo. Ainda no plano geral de reforma de nossas codificações, anuncia-se a próxima publicação do "Anteprojeto" do Prof. Torvaghi, para o nôvo Código Processual Penal brasileiro. Esperamos que êsse estatuto, diante do acúmulo de falhas do vigorante, possa traçar normas mais sadias para a sua própria exeqüibilidade, inclusive adotando o princípio da identidade física do juiz, que, embora matéria de natureza processual, foi esboçado no final dos artigos que acolhem a individualização da pena nos Códigos Penais do México e da Argentina;

6. $\left.{ }^{a}\right)$ Se a individualização judicial da pena se tem mostrado falha, que não dizer de sua individualização executória. A falta de estabelecimentos adequados para o cumprimento das providências preconizadas pelos códigos penais, especialmente no setor das medidas de segurança, tem impedido sua total aplicabilidade e se constituido num dos fatôres determinantes da instabilidade legislativa do Direito latino-americano.

O sistema progressivo, acolhido por muitos dêsses códigos, figura, não raro, só no texto da lei. E não se diga que tal fato se observa apenas nos chamados países subdesenvolvidos, que, à míngua de recursos, não podem oferecer aos reeducandos o tratamento preconizado pela lei. Marc Ancel, na sua monografia "Les Mesures de Sureté en Matière Criminelle", estudando a aplicação das medidas de segurança em 19 países de diferentes continentes, inclusive em centros de adiantado desenvolvimento cultural, notou a mesma ocorrência. Quase que de maneira geral, as medidas de segurança — diz êle - não passam de "penas complementares", dada a falta de aparelhamento necessário à sua melhor aplicação.

Um perfeito sistema penitenciário, com a padronização de estabelecimentos e órgãos técnicos necessários, é o dese- 
jável complemento para uma feliz política de individualização penal, pois é na fase executória, conforme salienta Siracusa $^{77}$, que a adequação da sanção à pessoa do delinqüente se revela como admirável conquista da legislação moderna.

40. Com essas medidas e outras de menor relevância, poder-se-á dar plena vitalidade ao instituto da individualização da pena e oferecer aos juízes os meios necessários para enfrentar as contraprovas da experiência.

77. Francesco Siracusa, Istituzioni di Diritto Penintenziario, Milão, 1935, p. 109. 